WHOI $-80-70$

Woods Hole

COPY 1
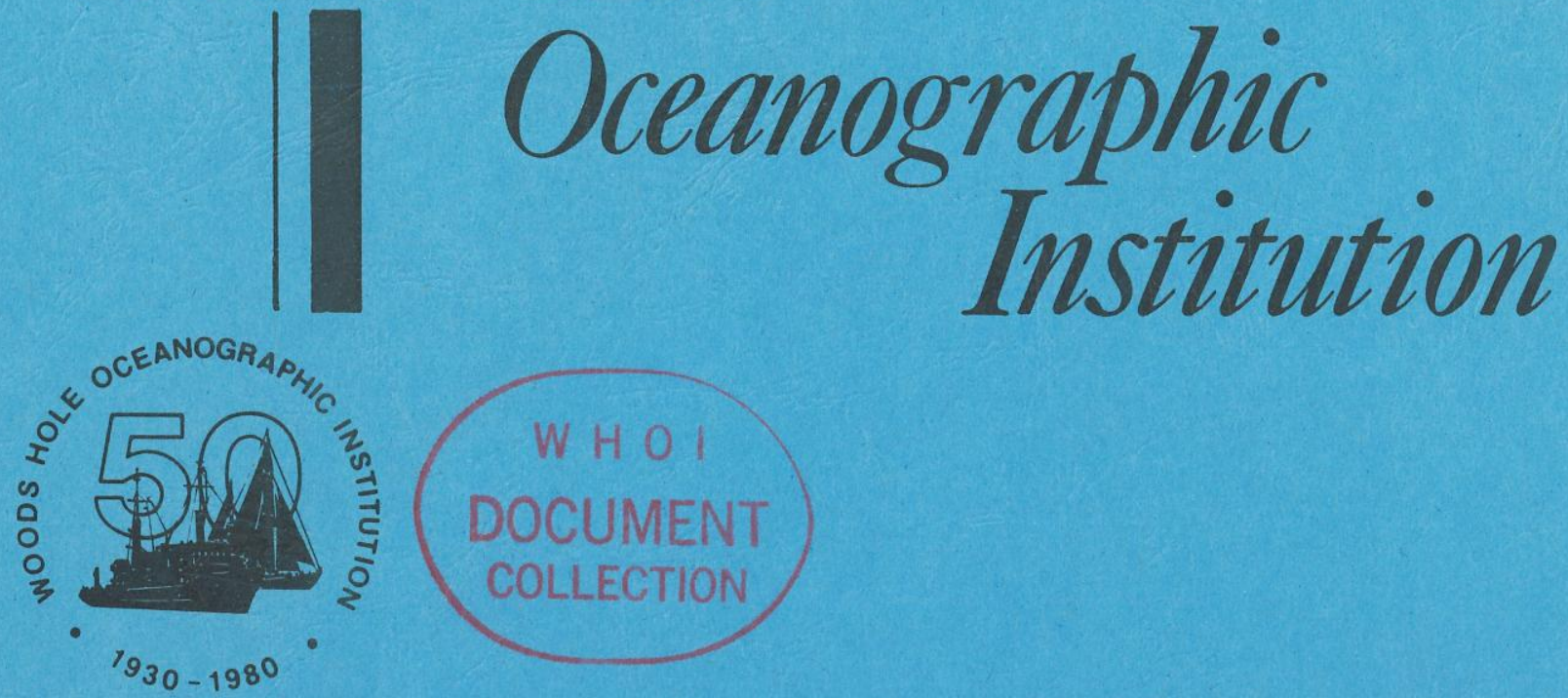

ANOMALOUS WATER MASS DISTRIBUTIONS AT 55W

IN THE NORTH ATLANTIC IN 1977

by

Michael S. McCartney,

L. Valentine Worthington and

Mary E. Raymer

December 1980

TECHNICAL REPORT

Prepared for the Office of Naval Research under Contract N00014-74-C-0262; NR 083-004, N00014-76-C-0197; NR 083-400 and for the International Decade of Ocean Exploration Office of the National Science Foundation under Grant OCE 75-03962.

Approved for public release; distribution unlimited.

WOODS HOLE, MASSACHUSETTS 02543 
WHOI $-80-70$

ANOMALOUS WATER MASS DISTRIBUTIONS AT 55W

IN THE NORTH ATLANTIC IN 1977

by

Michaet S. McCartney, L. Valentine Worthington and Mary E. Raymer

WOODS HOLE OCEANOGRAPHIC INSTITUTION

Woods Hole, Massachusetts 02543

December 1980

TECHNICAL REPORT

repared for the Office of Naval Research under Contract N00014-74-C-0262; NR 083-004, N00014-76-C-0197; NR 083-400 and for the International Decade of Ocean Exploration Office of the National Science Foundation under Grant OCE 75-03962.

Reproduction in whole or in part is permitted for any purpose of the United States Government. In citing this report in a bibliogrophy, the reference given should be "Journal of Marine Research, Volume 38, 1, 1980, pp. 147-172".

Approved for public release; distribution unlimited. Approved for Distribution: Valentine Worthington, Chairman Department of Physical Oceanography 


\title{
Anomalous water mass distributions at 55W in the North Atlantic in 1977
}

\author{
by Michael S. McCartney, ${ }^{1}$ L. Valentine Worthington ${ }^{1}$ and Mary E. Raymer ${ }^{1}$
}

\begin{abstract}
A hydrographic section made in July 1977 from the research vessel KNORR revealed a large-scale meridional distortion of the normal water mass distributions at $55 \mathrm{~W}$ in the North Atlantic. Cells of pure Labrador Sea Water were found within both the Gulf Stream and the westward recirculation of the gyre. A large cell of Mediterranean Water was found in the Slope Water, in contact with a cell of Subarctic Intermediate Water. Water at $11^{\circ} \mathrm{C}$ to $13^{\circ} \mathrm{C}$ within both the Gulf Stream and the Slope Water was anomalously saline. Throughout the Slope Water, Gulf Stream, and northern Sargasso Sea there was very little standard Western North Atlantic Water in the temperature ranges $3.4^{\circ}$ to $9.0^{\circ} \mathrm{C}$ and $11^{\circ}$ to $13^{\circ} \mathrm{C}$. It is suggested that these meridional distortions are due in part to an increase in the amount of rotation of the horizontal velocity vector with depth during 1977 that was observed with current meters in the northern Sargasso Sea. An increase in the westward return flow strength may also have contributed. The ultimate cause of the anomalous property distributions and currents may be changes in the production rate and strength of the source waters for North Atlantic Deep Water and western North Atlantic Water such as Labrador Sea Water, Mediterranean Water, and Eighteen Degree Water. The first and the last are known to have undergone convective formation events, in March 1976, and March 1977, respectively, in the period preceding the 1977 survey. The July 1977 section shows evidence of the recirculation of the new convectively formed Eighteen Degree Water.
\end{abstract}

\section{Introduction}

A fundamental question for the understanding of the larger scale general circulation of the ocean is the nature of the processes maintaining the tight propertyproperty correlations of the thermoclinic and deep waters of the world's oceans. The temperature-salinity correlation within the Sargasso Sea main thermocline (warmer than $4^{\circ} \mathrm{C}$ ) was named Central Atlantic Water by Iselin (1936). The Western North Atlantic Water, as Iselin's correlation is now generally called (Wright and Worthington, 1970), is characterized by a nearly linear temperature salinity relationship between about $18.5^{\circ} \mathrm{C}, 36.53 \%$ and $11.0^{\circ} \mathrm{C}, 35.41 \%$, curving at colder temperatures down to $4.0^{\circ} \mathrm{C}, 34.99 \%$. This water mass spans the main thermocline from the Eighteen Degree Water (Worthington, 1959) that caps the

1. Woods Hole Oceanographic Institution, Woods Hole, Massachusetts 02543, U.S.A. 
Table 1. The percent of the total North American basin volume in the indicated temperature interval that is found in the tabulated salinity range. The data set is the North American basin chart of Wright and Worthington (1970). Also tabulated are the Western North Atlantic water standard salinities for those temperatures.

\begin{tabular}{|c|c|c|c|}
\hline $\begin{array}{l}\text { Temperature } \\
\text { Interval }\end{array}$ & $\begin{array}{l}\text { Salinity } \\
\text { Range }\end{array}$ & $\begin{array}{c}\text { Percent of total volume } \\
\text { in temperature interval } \\
\text { that is found in the } \\
\text { salinity range }\end{array}$ & $\begin{array}{l}\text { Western North } \\
\text { Atlantic water } \\
\text { standard salinity }\end{array}$ \\
\hline $\begin{array}{c}14^{\circ} \mathrm{C} \text { (in situ) } \\
\text { to }\end{array}$ & $\begin{array}{l}35.9 \% \\
\text { to }\end{array}$ & $89 \%$ & $35.840 \%$ \\
\hline $13^{\circ} \mathrm{C}$ (in situ) & $35.7 \%$ & & $35.680 \%$ \\
\hline $\begin{array}{l}6.5^{\circ} \mathrm{C} \text { (in situ) } \\
\text { to }\end{array}$ & $\begin{array}{l}35.15 \% \\
\text { to }\end{array}$ & $86 \%$ & $35.047 \%$ \\
\hline $6.0^{\circ} \mathrm{C}$ (in situ) & $35.00 \%$ & & $35.030 \%$ \\
\hline $\begin{array}{l}4.0^{\circ} \mathrm{C} \text { (potential) } \\
\text { to }\end{array}$ & $\begin{array}{l}35.06 \% \\
\text { to }\end{array}$ & $95 \%$ & $34.993 \%$ \\
\hline $3.8^{\circ} \mathrm{C}$ (potential) & $34.96 \%$ & & $34.987 \%$ \\
\hline
\end{tabular}

main thermocline to the top of the cold deep water of polar and subpolar origins. The volumetric temperature-salinity distributions of the North Atlantic are very sharply peaked at this curve, as indicated by Table 1 (Wright and Worthington, 1970). According to Worthington (1976), the Gulf Stream system normally transports only Western North Atlantic Water. This is part of his rationale for closing the Sargasso Sea circulation streamline fields north and west of the saline Mediterranean influence.

Because of this tightness of the temperature-salinity correlation, vertical profiles of temperature and salinity contain a large common signal. If one prepares vertical sections of temperature and salinity and compares them side by side, the shapes of the isopleths will be visually quite similar, and only by overlaying the two sections will systematic differences in shape become apparent: the isohalines will often cross the isotherms at very small angles. A technique for removing the common information contained in the two sections was developed by Helland-Hansen and Nansen (1926). A salinity anomaly as a function of temperature is calculated by subtracting a regional standard salinity at that temperature from the observed salinity at that temperature. A vertical temperature section can then be produced with superimposed contour of this salinity anomaly, and the interpretation is generally much easier than it would be using the actual salinity. Similar reasoning leads to the use of oxygen anomaly section and silicate anomaly sections. In the present paper we will use only salinity and silicate anomalies. Presuming that a proper regional curve has been used, one often finds a region of near zero anomaly with neighboring areas of significantly positive or negative anomalies, i.e. the anomaly field is not random, but has systematic trends interpretable in terms of water mass sources and mixing. 


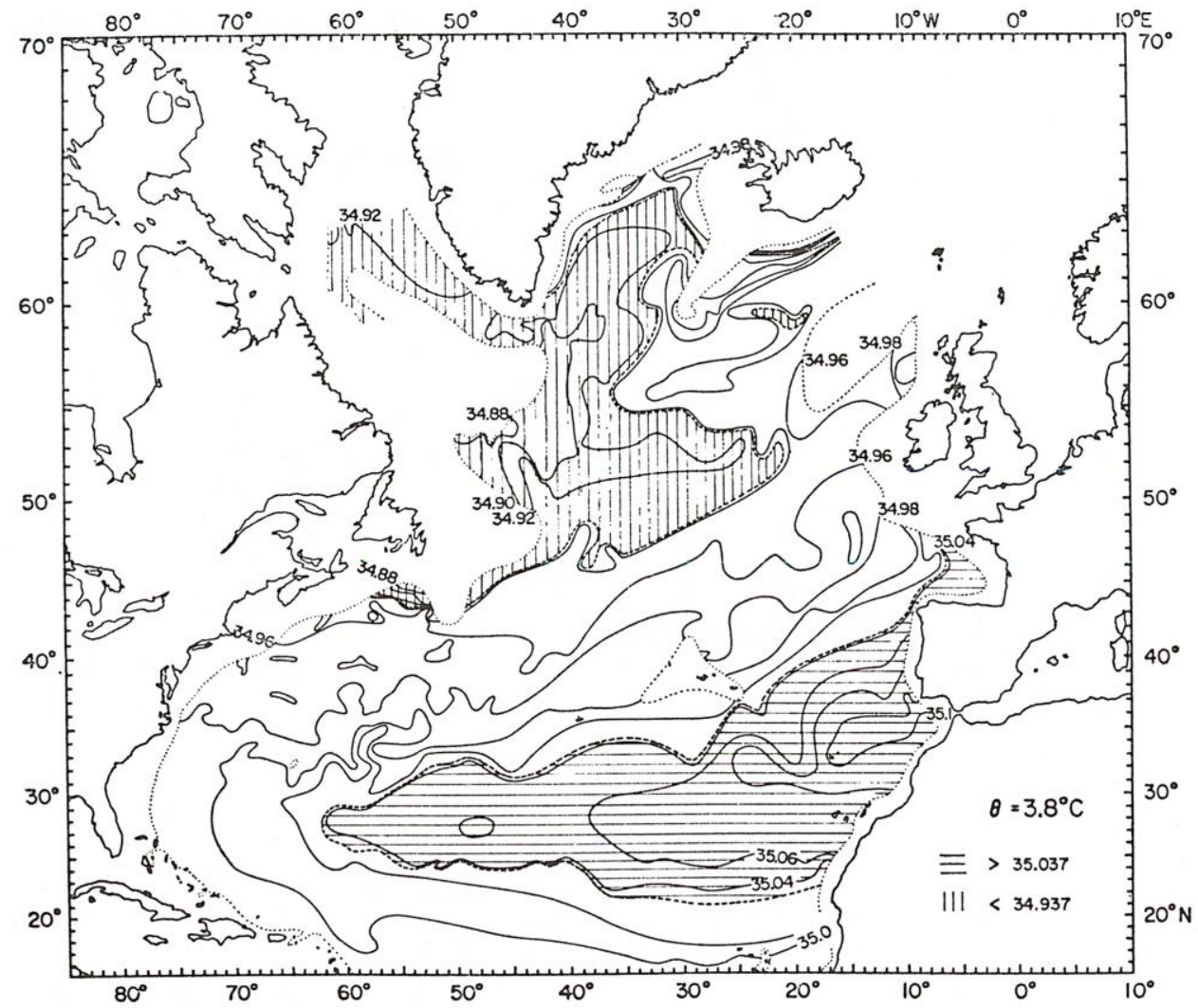

Figure 1. Charts of salinity on constant temperature surfaces in the North Atlantic Ocean. The hatching indicates the area with salinities different by more than $.05 \%$ from the Western North Atlantic Water standard salinity at that temperature. The horizontal hatching indicates salinities greater than the standard by more than $.05 \%$. The vertical hatching indicates salinities less than the standard by more than $.05 \%$. a) $3.8^{\circ} \mathrm{C}$ potential temperature, standard salinity $34.987 \%$ o. b) $6{ }^{\circ} \mathrm{C}$ in situ temperature, standard salinity $35.030 \%$. c) $13^{\circ} \mathrm{C}$ in situ temperature, standard salinity $35.680 \%$.

One could similarly use an anomaly in horizontal charts. A commonly used horizontal chart is salinity on a constant temperature surface. Here the use of an anomaly just means relabeling the contours on the chart, so it usually is not done. In Figure 1, three such charts are shown, for $3.8^{\circ} \mathrm{C}$ (potential), $6.0^{\circ} \mathrm{C}$ (in situ) and $13.0^{\circ} \mathrm{C}$ (in situ). The selection of these particular surfaces was made to provide the background oceanwide salinity field for later use in addressing some particular observations near these temperatures from the eastern Sargasso Sea. Other temperature surfaces have been presented in Worthington and Wright (1970), Worthington (1970) and Worthington (1976). 


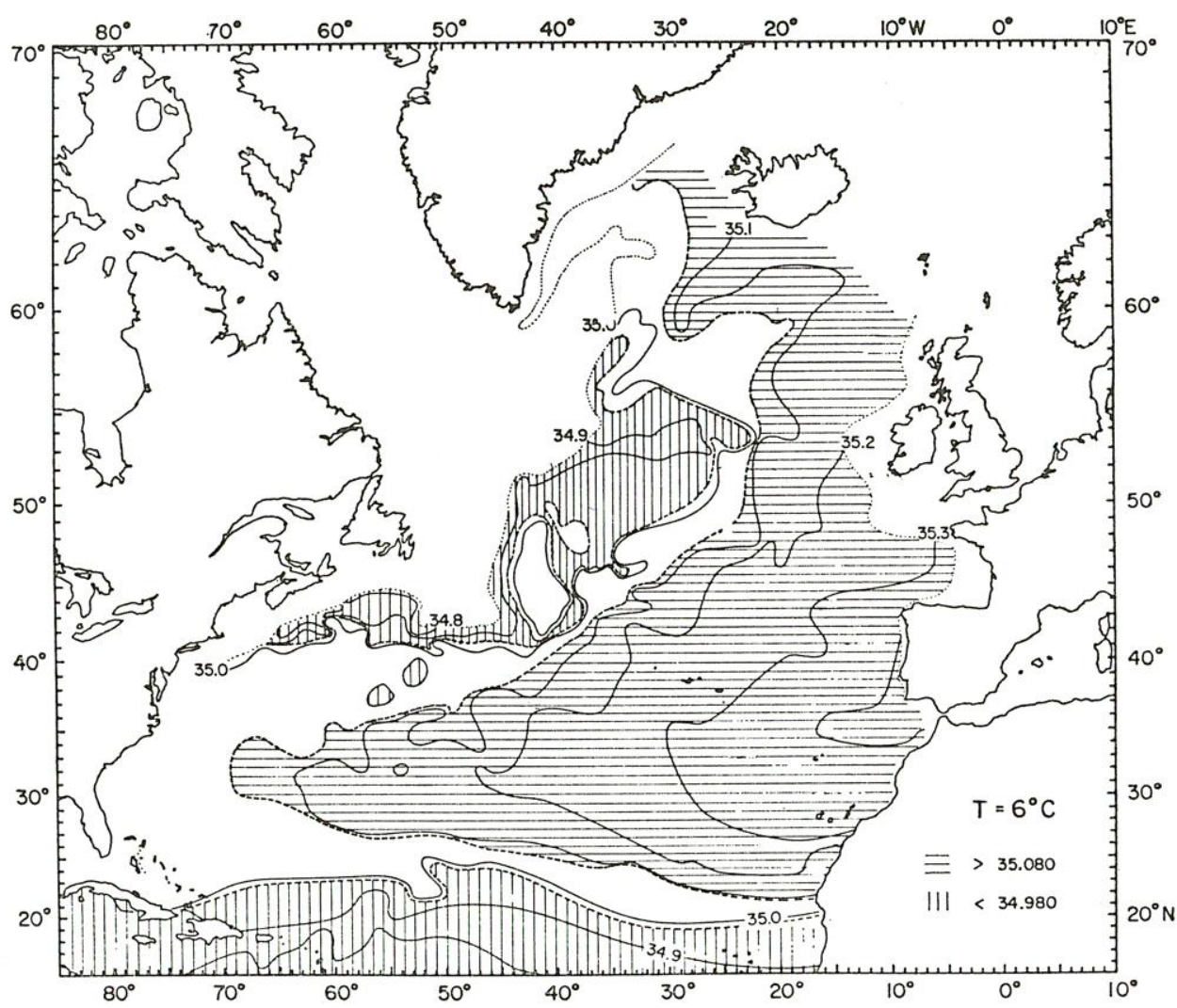

In this paper, we will examine two hydrographic sections made nine months apart along 55W, extending from the Slope Water across the Gulf Stream, and across the Sargasso Sea gyre recirculation south to about $31 \mathrm{~N}$. These sections were made in support of a field investigation of the eddies and the mean flows in the deep ocean in the neighborhood of the Gulf Stream and the westward recirculation to its south. A number of results from the current meter array have been described in a sequence of three papers (Schmitz, 1977, 1978, and 1979).

The comparison and contrast of the two hydrographic sections is made from two perspectives. The more general one uses salinity anomaly and silicate anomaly sections to delineate the changes in water mass characteristics that took place in the nine month period. The changes were dramatic. In summary, during that period a large scale meridional layering of the water column warmer than $3^{\circ} \mathrm{C}$ took place. Cells of excessively salty or excessively fresh water were found far to the northwest and southwest, respectively, of their normal locations. The cell dimensions ranged from tens of kilometers to six hundred kilometers. Ultimately, mixing would erode them producing a small salinity anomaly water mass. We speculate that this event 


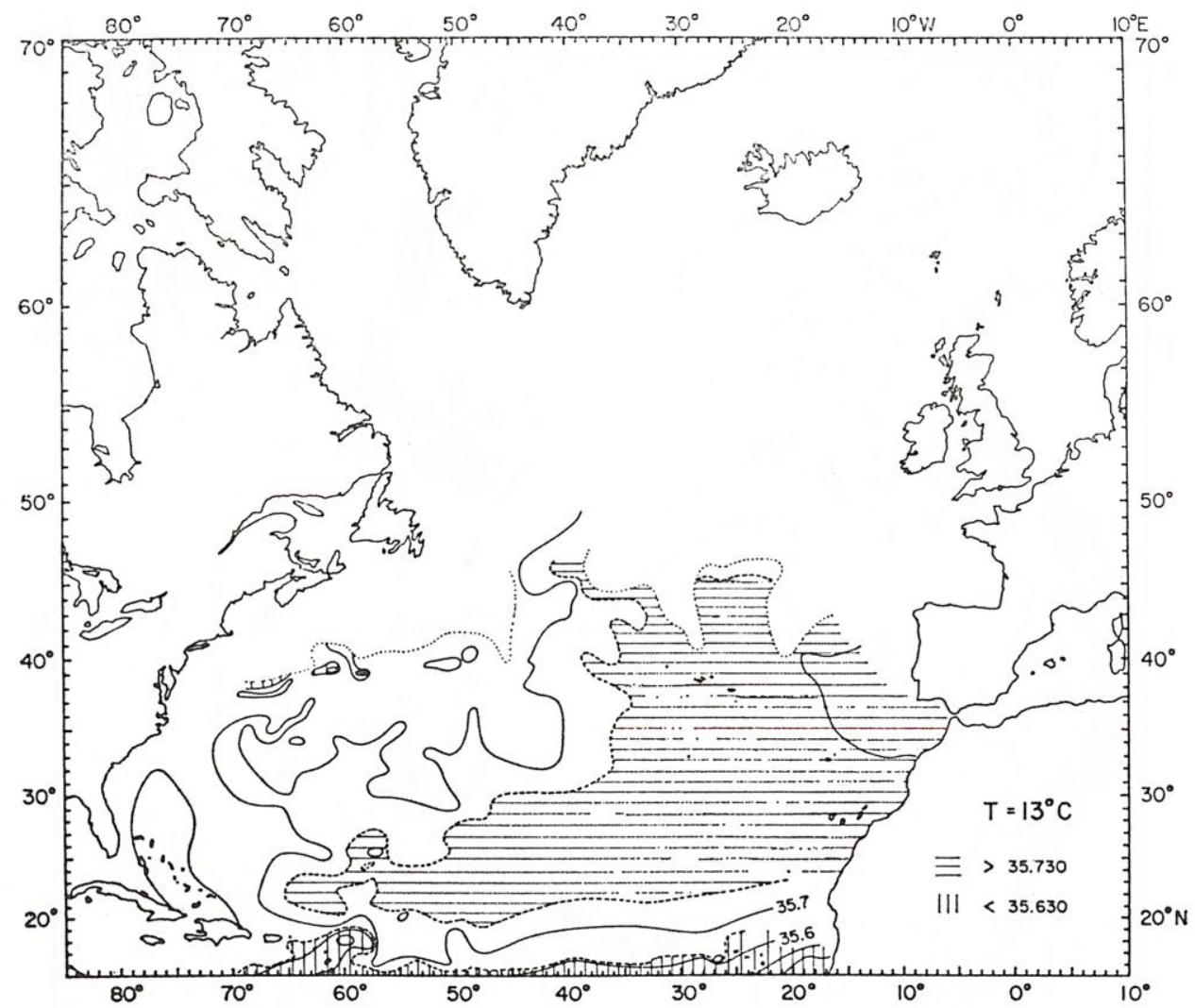

may represent the Western North Atlantic maintenance mechanism. One could envision a stationary process in which the characteristics of a large pool of water are maintained by steady mixing inputs from peripheral sources. The observations described in this paper lead us to suggest a more event oriented process. Occasionally, a large scale layering event occurs involving intrusions of the peripheral source waters into the interior of the Sargasso Sea. This is probably also "occasional" in space. The erosion process may be fairly rapid and the end product, Western North Atlantic Water, may recirculate within the gyre many times before the next event. Possibly the trigger for the layering events is related to source water formation events. Two of the source waters for the Western North Atlantic Water are known to have undergone convective formation events. The Eighteen Degree Water in the northwestern Sargasso Sea convectively overturned in March-April 1977 (Leetmaa, 1977; Worthington, 1977), the first time this had occurred in three years. In the western Labrador Sea, deep convective overturning was observed in March-April 1976 at the densities associated with Labrador Sea Water (personal communications, Lazier, 1977, Gascard, 1979). This may have been the first Labrador Sea Water 


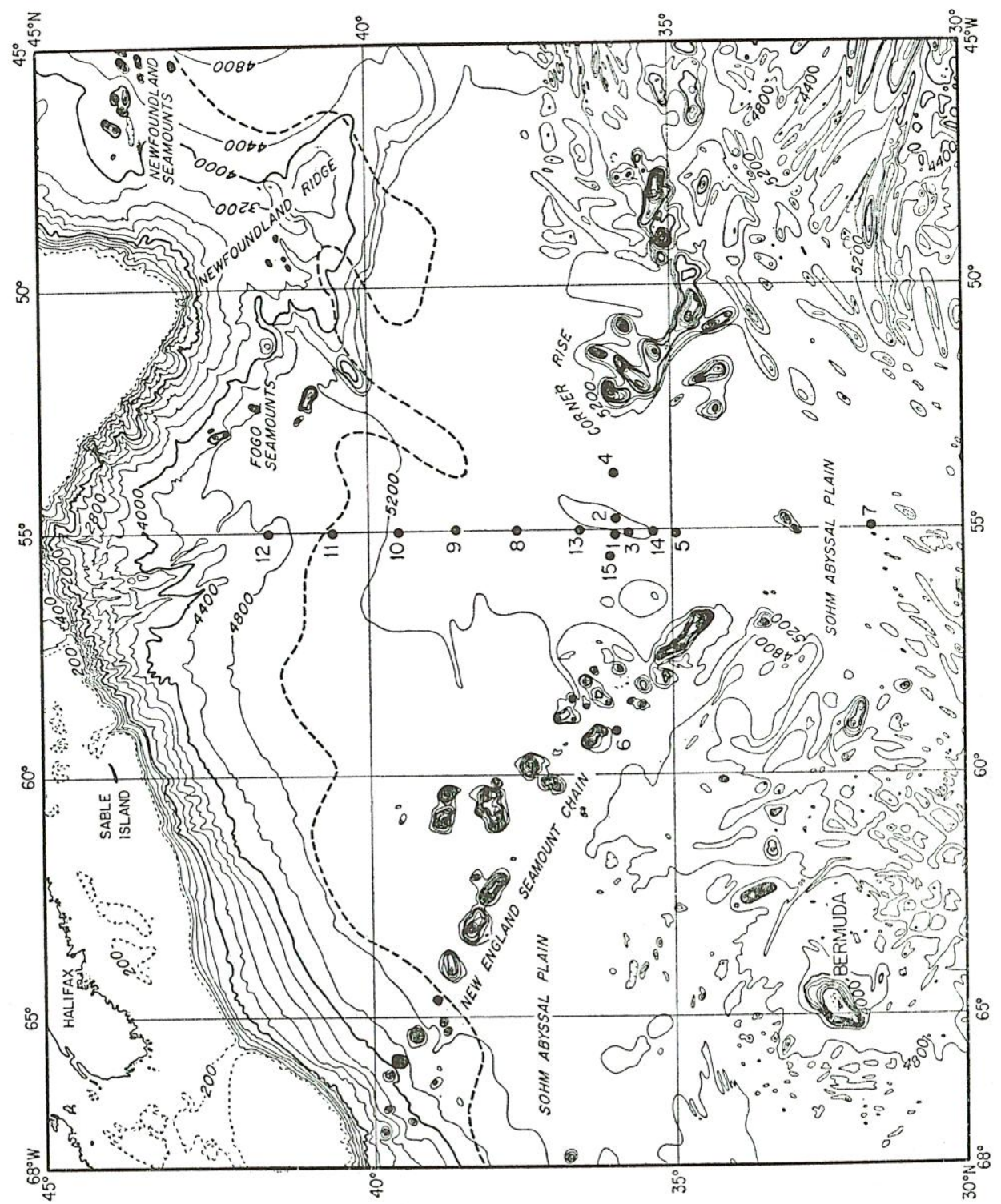

Figure 2a. Location of mooring sites for POLYMODE Array 2, superimposed on a chart of the regional bottom topography, adapted from Uchupi (1971). The dashed line is the mean position of the $15^{\circ}$ isotherm at $200 \mathrm{~m}$ according to Schroeder (1963). This is an indicator for the axis of the Gulf Stream. After Schmitz, 1979.

Formation event in more than a decade. These convective overturning formation events involve the conversion of warmer waters to cooler. One can think of the Labrador Sea Water convective region as the poleward side of a meridional circula- 
tion cell in which warmer waters move north, are cooled and converted to Labrador Sea Water, and return south to subtropical latitudes at depth. There the cell is completed by heating - either vertical (down gradient) or isopycnal (down gradient, since the waters to the south at this density are saltier and warmer). An increase in the production rate of Labrador Sea Water would lead to an increase in the southward flux in the lower limb as well as in the northward flux of the warm limb of the cell. At subtropical latitudes the result would be an increased contrast between the waters at main pycnocline densities compared to Labrador Sea Water densities, much like the layering we observed.

The second perspective is a more narrow one. The variation along the two sections of the thickness of the Eighteen Degree Water (Worthington, 1959) is examined by a pycnostadal analysis technique. Embedded within the pycnoclines of the world's oceans are often layers of nearly homogeneous water (Worthington, 1972; Masuzawa, 1969; McCartney, 1977; McCartney and Talley, 1979)—pycnostads (Seitz, 1967). Their origins often can be traced to winter convective homogenization in polar and subpolar regions. Eighteen Degree Water is the archetype of this Mode Water family. A quantitative index of the relative homogeneity of the pycnostad is the Brunt-Väisälä period of a density interval spanning the pycnostad. Examining the variation of the density and Brunt-Väisälä period of the Eighteen Degree Water along the two sections reveals a clear signal of the formation event that is known to have occurred during the period between the two cruises (Leetmaa, 1977) as well as a systematic density variation related to the variation of Eighteen Degree Water temperature in the formation regions, and the streamline field of the gyre recirculation.

\section{The data sets}

The location of the POLYMODE Array 2 moorings are shown in Figure 2a. The hydrographic program on the two KNORR cruises involved 29 bottle Nansen stations at locations between moorings, and full water column continuous profiles of temperature, salinity and oxygen, using a Neil Brown Instrument System CTD, at the mooring sites. On KNORR 66, a 24-bottle rosette sampler was used, and some of these CTD stations with 24 bottles were made in concert with 16-bottle Nansen casts to give 40-bottle stations. Water samples were processed for salinity, oxygen, and silicate. Figure $2 \mathrm{~b}$ shows the relationship of the KNORR 60 and 66 hydrographic programs to the POLYMODE Array 2 mooring locations.

In the data presentation and discussion considerable use is made of salinity anomaly, i.e. the difference between the observed salinity at an observed temperature and a Western North Atlantic Water standard salinity at the same observed temperature. The standard relation is a composite of the Worthington and Metcalf (1961) North Atlantic Deep Water potential temperature-salinity curve for less than 


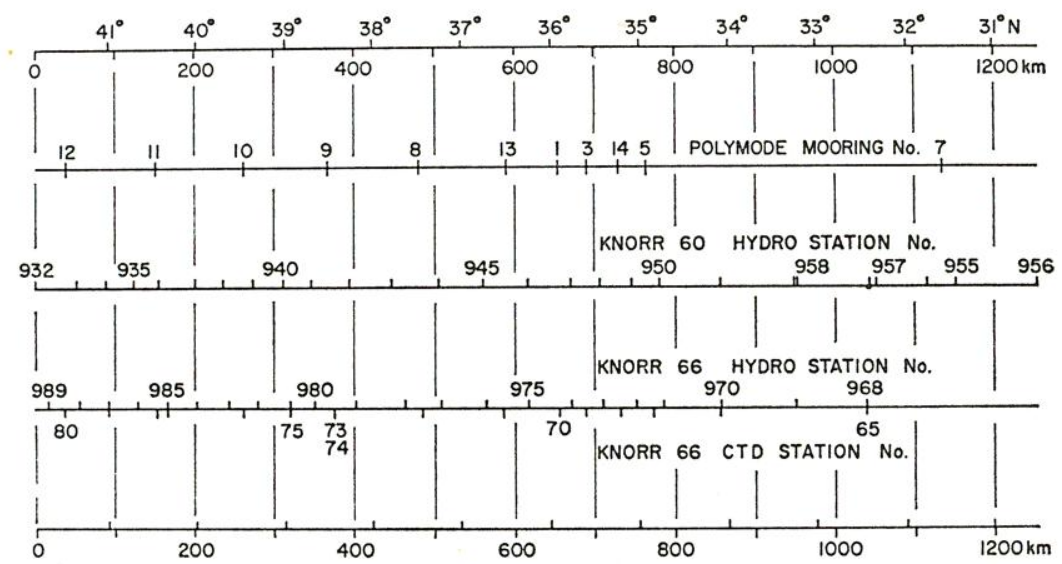

Figure 2b. Locations along 55W of the POLYMODE Array 2 moorings, the hydrographic stations from KNORR 66 and the hydrographic and CTD stations from KNORR 66, relative to distance along the section, and latitude.

$4^{\circ} \mathrm{C}$, the Iselin (1936) temperature salinity curve from $4^{\circ} \mathrm{C}$ to $18^{\circ} \mathrm{C}$, and an unpublished curve by Fuglister that extends the Iselin curve to water warmer than $18^{\circ} \mathrm{C}$.

A similarly defined silicate anomaly is also used, which is particularly useful in the deeper water where salinity variations are very small. This curve was constructed from a heavily sampled station line along 64 $30^{\prime} \mathrm{W}$ occupied in April 1974 (KNORR 48). Needell (1979) has examined a larger data set from this region and arrived at an identical curve-within the accuracy of the silicate measurement and the regional scatter of the data. The standard deviation of the envelope of silicate values in the potential temperature range $1.7^{\circ}$ to $4.2^{\circ} \mathrm{C}$ is about $1 \mu \mathrm{g} A / l$. Silicate anomalies of magnitude greater than $2 \mu \mathrm{g} A / l$ start showing correlation with the current patterns deduced from isopycnal tilts. In sections presented in this paper, we only indicate regions of silicate anomaly greater than magnitude $5 \mu \mathrm{g} A / l$.

For each cruise data set, we present two sections: the potential temperature fields in Figure 3, and the anomaly fields in Figure 4. The salinity anomaly is used above 2500 meters, the silicate anomaly below 2500 meters. Supplementary temperature data from XBT's have been used above 760 meters in Figure 3. The KNORR 60 CTD data was inspected to ensure that no salinity anomalies were missed, but the data were not included in either Figure 3 or Figure 4. The KNORR 66 CTD data were used in both figures. This accounts for the somewhat greater wiggliness in the deep water of the latter section, but not for the presence of the larger amplitude anomalies at short horizontal scales in the latter section. We have included the charts of Figure 1 to aid in interpreting the section anomaly fields relation to the basin wide salinity field of the North Atlantic. The charts of Figure 1 include dashed contours at the 5 anomaly boundaries. 


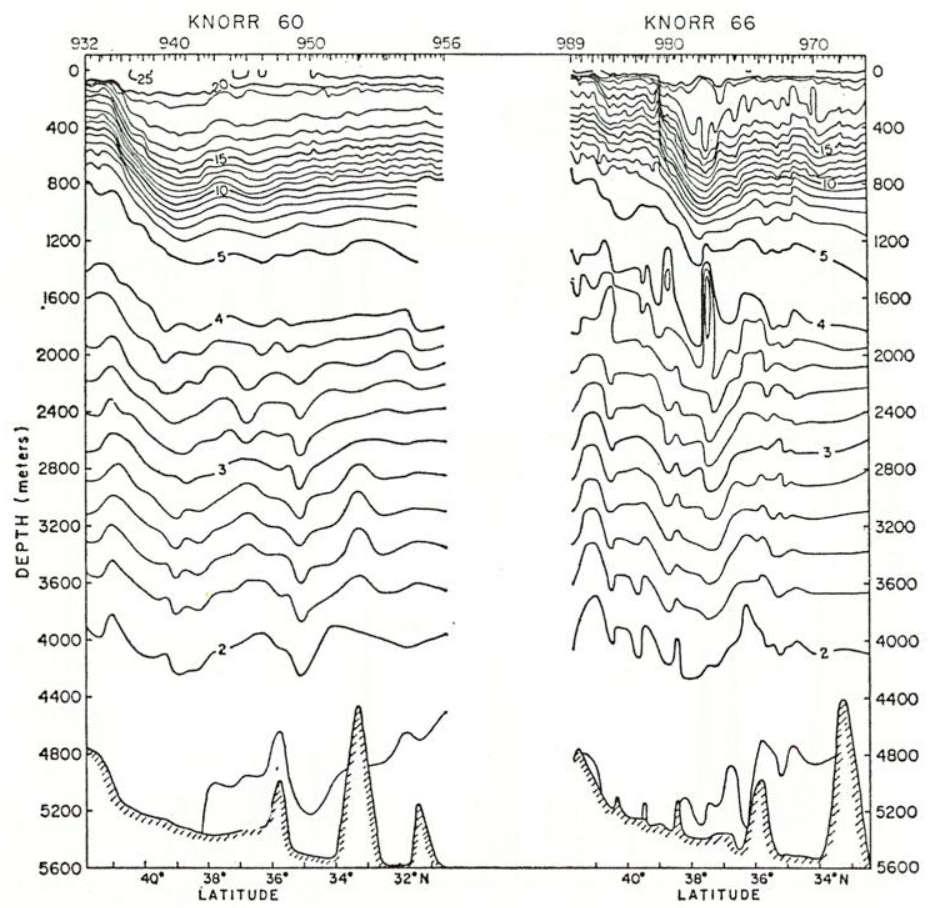

Figure 3. Temperature sections from KNORR 60 hydrographic stations, and XBTs to 750 meters, and from KNORR 66 hydrographic stations, XBTs to 750 meters, and CTDs.

\section{Description of the sections}

a. The KNORR 60 section. The temperature section from KNORR 60 (Figure 3a) shows the Gulf Stream near the historical normal latitude. The occurrence of $15^{\circ} \mathrm{C}$ at 200 meters, the traditional indicator of the axis of the Gulf Stream, is found at about $41 \mathrm{~N}$. The eastward transport of the Gulf Stream relative to the bottom between stations 934 and 940 is calculated to be $89 \times 10^{8} \mathrm{~m}^{3} / \mathrm{sec}$. The main thermocline slopes upward gradually to the south of the gyre center (station 940). This is the broad baroclinic signature of the subtropical recirculation south of the Stream. The westward transport between stations 940 and 952 relative to the bottom is 58 $\times 10^{6} \mathrm{~m}^{3} / \mathrm{sec}$. The section does not extend far enough to the north to deduce the existence or nonexistence of the Slope Water Counter Current.

The anomaly section (Figure 4a) shows five areas of departure greater than magnitude 5 from Western North Atlantic Water and North Atlantic Deep Water. To the north in the shallow water are expected negative salinity anomalies at temperatures warmer than about $7^{\circ} \mathrm{C}$ (McLellan, 1957). The Eighteen Degree Water within and to the south of the Stream shows significant abnormal negative salinity anomalies. 


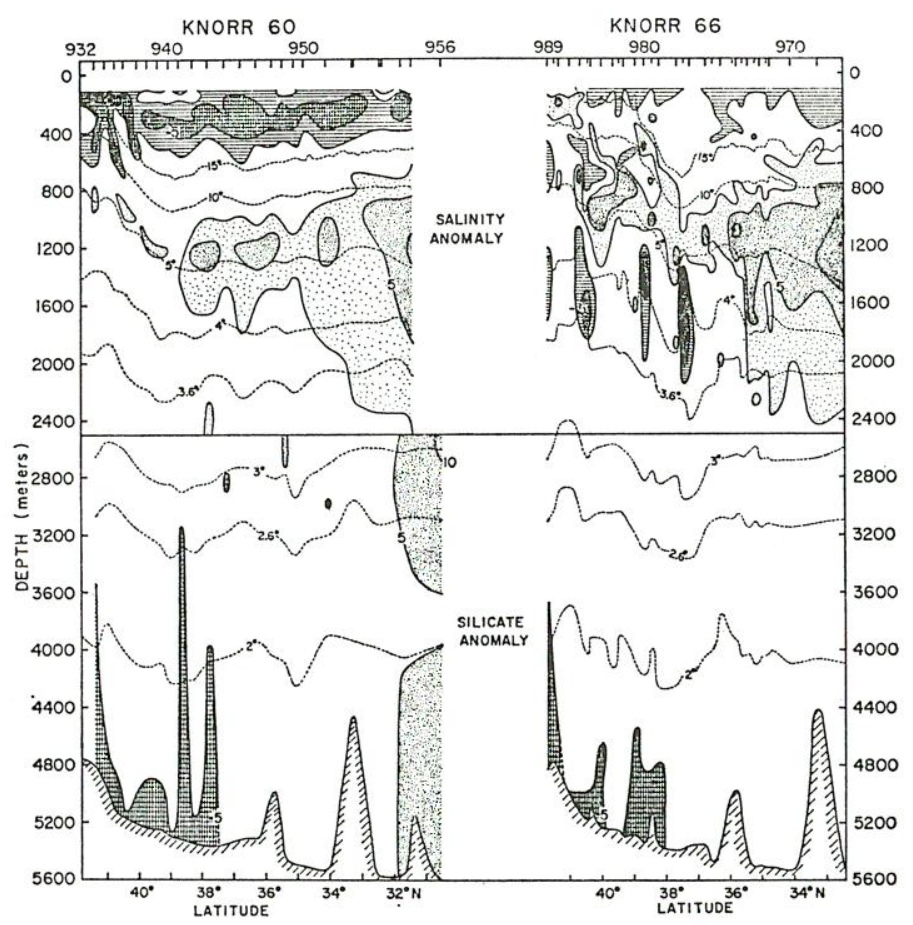

Figure 4. Anomaly sections from KNORR 60 hydrographic stations, and from KNORR 66 hydrographic stations and CTDs. Salinity anomalies in hundredths of a part per thousand are contoured above 2500 meters, while silicate anomalies in microgram atoms per liter are contoured below 2500 meters. Only anomalies of greater magnitude than 2.0 are shaded, with dots for position anomalies, slashes for negative anomalies. The contours are $\pm 2, \pm 5$, \pm 10 , with the regions of magnitude of 5 or more having double intensity shading.

At the base of the main thermocline and in the upper deep water the influence at the Mediterranean outflow is seen by positive salinity anomalies. The strongest influence is south of the main recirculation, south of $33 \mathrm{~N}$, although the weaker Mediterranean influence penetrates through the recirculation part of the subtropical gyre (as defined by the main thermocline isotherm slopes). The presence of positive salinity anomaly water north of the recirculation is suggestive of a participation of some Mediterranean water in the eastward flow in the Gulf Stream zone of the gyre, as well as the westward recirculation zone. Schmitz (1979) reports a well-defined eastward mean flow at $37^{\circ} 30^{\prime} \mathrm{N}$.

In the anomaly sections, negative silicate anomalies of magnitude greater than $5 \mu \mathrm{g} A / l$ are found in the deep water of the northern part of the section. These represent the southwestward penetration of the low silicate Denmark Strait Overflow Water into the western North Atlantic. Denmark Strait Overflow Water is characterized in the Labrador Sea by low silicate content, relative to the North Atlantic Deep 
Water of the Sargasso Sea (Metcalf, 1969). The 4000 meter 27 month mean velocities from the POLYMODE Array 2 current meters, Schmitz (1979), show a welldefined westward flow between 39 and $41 \mathrm{~N}$, and an eastward flow between 37 and $38 \mathrm{~N}$. The westward flow is beneath the historical position of the near surface expression of the Gulf Stream $-15^{\circ} \mathrm{C}$ at 200 meters. The $4000 \mathrm{~m}$ eastward flow is about 200-300 kilometers to the south of the historical Gulf Stream axis. The silicate anomaly distribution shows a somewhat bimodal distribution. The northern region of low silicate is associated with the westward mean flow, while the southern falls near the eastward mean flow. An interpretation is that the western flow carries the Overflow Water west along the continental slope to the Cape Hatteras area, where it is documented that the Gulf Stream crosses over these denser waters (Richardson, 1977). Part of the Overflow Water flows back east with the Gulf Stream system giving the second low silicate core at $55 \mathrm{~W}$. We thus conjecture that not all the Western Boundary Current waters continue south at Cape Hatteras: some portion turns east with the Gulf Stream.

To the south in the deep water are positive silicate anomalies reflecting the general north to south increase in silicate that occurs in the Atlantic Ocean. Worthington (1976) noted that this high silicate water lies south of the deep return flow of the Gulf Stream System, and the geostrophic shear calculations that will be discussed below tend to confirm this notion. He ruled out the deep return flow passing through this high silicate water where it would acquire silicate. This acquired silicate would have to be removed from the return flow before it turns north and east to become part of the Gulf Stream. On this basis, he closed the deep circulation gyre north of the high silicate region. The current measurements reported by Schmitz (1977, $1978,1979)$ do show little or no mean current in this high silicate water whereas the mean deep currents $(>4000 \mathrm{~m})$ in the zero anomaly silicate water are very strong indeed, both in the vicinity of the Gulf Stream and the return flow.

b. The KNORR 66 section. The KNORR 66 temperature section (Figure 3b) shows the Gulf Stream shifted about 200 kilometers south from its location during KNORR 60. While the position has shifted, the transport is virtually identical to the KNORR 60 value. Between CTD stations 76 and 72 (positions on Fig. 2b) the transport relating to the bottom is $90 \times 10^{6} \mathrm{~m}^{3} / \mathrm{sec}$. The rising of the main thermocline southward of the gyre center (CTD Station 72) is considerably steeper than during KNORR 60. The subtropical recirculation between CTD station 72 and hydrographic station 975 is about $60 \times 10^{6} \mathrm{~m}^{3} / \mathrm{sec}$, quite close to the KNORR 60 value. The stations defining the effective southern boundary of the recirculation for the two cruises are those for which $15^{\circ} \mathrm{C}$ has risen above 550 meters. This convenient indicator also marks the approximate northern limit of the continuous $+.05 \%$ positive salinity anomaly at the main thermocline base. On KNORR 60 this boundary was at $33 \mathrm{~N}$, on KNORR 66 it was at $36 \mathrm{~N}$. South of station 975 changes in tempera- 


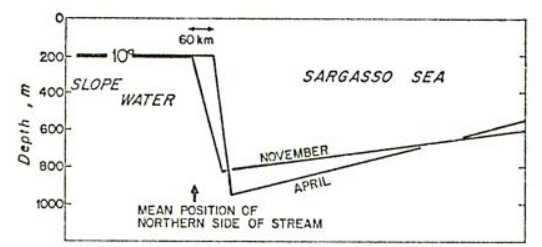

Figure 5. From Worthington (1976). A schematic of the apparent annual changes in the volume transport and the north-south displacement of the Gulf Stream.

ture are compensated by changes in salinity, so there is almost no baroclinic transport relative to the bottom.

The more northern location of the southern recirculation boundary combines with a more southern gyre center at CTD station 72 to give a much narrower baroclinic signal of the westward recirculation-about $150 \mathrm{~km}$ compared to 600-700 $\mathrm{km}$ on KNORR 60. Worthington (1976, chapter 18) has discussed the apparent seasonality of the transport and Gulf Stream recirculation locations. Figure 5 shows his schematic representation of the difference between late autumn and early spring thermocline structure. The difference in the Gulf Stream and the recirculation zone thermocline topography during KNORR 66 compared to KNORR 60 may therefore be a result of the Eighteen Degree Water overturning event that took place in early 1977 (Worthington, 1977).

North of the stream, the isotherm fields do not show a strong indication of the slope water countercurrent. The salinity variations do lead to a mild isopycnal slope reversal, and there is a Slope Water countercurrent of $12.5 \times 10^{8} \mathrm{~m}^{3} / \mathrm{sec}$, relative to the bottom.

The KNORR 66 anomaly section (Fig. 4b) shows a number of major changes compared to the KNORR 60 data. The upper waters of the Slope Water region show positive salinity anomalies up to $+.06 \%$. At the same temperature, near $13^{\circ} \mathrm{C}$, the Gulf Stream (station 72-76) is also transporting water with positive salinity anomalies, instead of the usual "zero" anomaly water. According to Figure 1a, such high salinities at $13^{\circ} \mathrm{C}$ are not generally found north of about $25 \mathrm{~N}$ along $55 \mathrm{~W}$, nor north of $30 \mathrm{~N}$ anywhere west of $40 \mathrm{~W}$.

The warm water south of the Gulf Stream is dominated by normal salinity Eighteen Degree Water, instead of the negative salinity anomaly water found there during KNORR 60. The evolution of the Eighteen Degree Water will be discussed further below.

The positive salinity anomaly signature of Mediterranean outflow influence in the lower thermocline and upper deep water has changed considerably. The continuous $+.05 \%$ now extends north to $36 \mathrm{~N}$ compared to $33 \mathrm{~N}$ in the earlier section. In the earlier section, the continuous $+.02 \%$ anomaly contour extends only to the gyre center at $39 \mathrm{~N}$. The KNORR 66 anomaly field shows this contour continuous across the Gulf Stream and some 250 kilometers into the Slope Water. There is a 200 


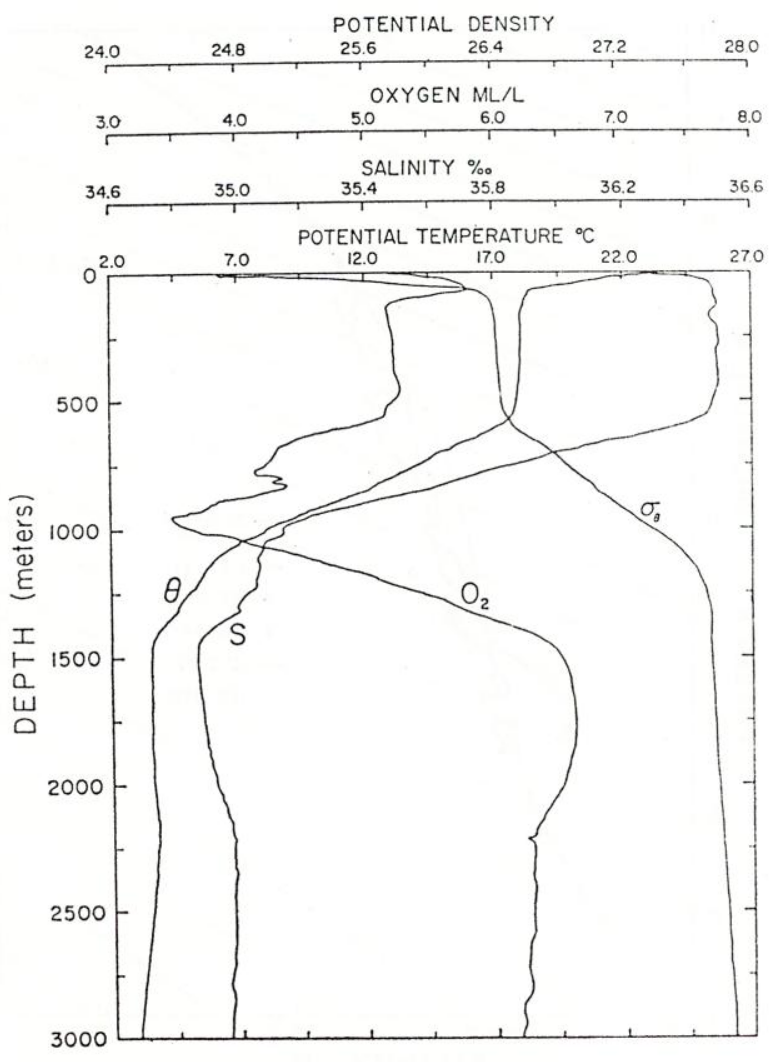

Figure 6. Continuous profiles of potential temperature salinity, dissolved oxygen and potential density from CTD station 72 on KNORR 66. Negative salinity anomalies of magnitude greater than $.02 \%$ are found between 1340 and 2150 meters. The continuous traces show this layer to be a potential temperature minimum, a salinity minimum, a dissolved oxygen maximum, and a minimum of vertical potential density gradient-a pycnostad. The abnormal thickness of the density layer amounts to about 375 meters.

kilometer lens of greater than $+.05 \%$ o between stations 981 and 985 , i.e. in the weak Slope Water countercurrent. Intermingled with this saline water are three cells of negative salinity anomaly water between $5^{\circ}$ and $10^{\circ} \mathrm{C}$.

In the upper deep water, the anomaly section shows four cells of negative salinity anomalies. Two are in the Slope Water, one beneath the core of the Gulf Stream, and the fourth beneath the gyre center. This southernmost one has the largest negative anomaly: $-.106 \%$, with associated potential temperature of $3.52{ }^{\circ} \mathrm{C}$, salinity $34.86 \%$, and dissolved oxygen of $6.51 \mathrm{ml} / l$.

The deep water silicate anomaly distribution is virtually unchanged from the earlier section. Since the Gulf Stream shifted to a more southern latitude at the KNORR 66 section, the southernmost low silicate core is now beneath the surface Gulf Stream, rather than south of it as in the earlier section. Thus, we find the near 


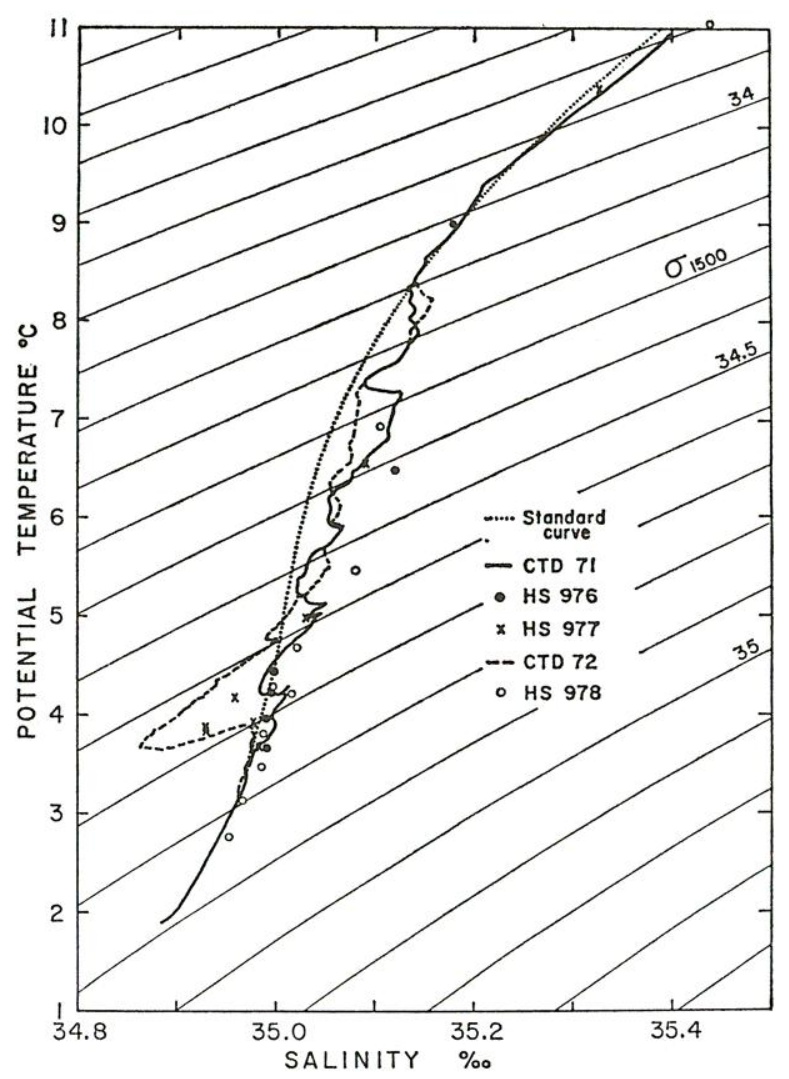

Figure 7. Potential temperature (referenced to 1500 decibars) salinity relationships for the stations associated with the southernmost Labrador Sea Water anomaly. Potential density anomaly curves are included, referenced to a pressure of 1500 decibars. The western North Atlantic standard relationship is shown for reference.

surface Gulf Stream moving relative to the deeper cores of Denmark Strait Overflow Water.

c. Temperature and salinity structure. The four cells of pronounced negative salinity anomaly in the KNORR 66 section in the upper deep water have associated temperatures between 3.5 and $4.5^{\circ} \mathrm{C}$, the southern three with temperature inversions. Figure 6 shows the CTD data profiles for station 72 at the southernmost cell. The anomaly is manifested by a potential temperature and salinity minimum, a dissolved oxygen maximum, and as a maximum in Brunt-Väisälä period-a pycnostad (Seitz, 1967). According to the charts of Talley and McCartney (1980), the CTD station 72 pycnostad core strength of 124 minutes (at $37^{\circ} 30^{\prime} \mathrm{N}$ ) would be equivalent to that found in summer in the formation region of Labrador Sea water near $55 \mathrm{~N}$, after correction for the latitudinal dependence of potential vorticity. A period of 
124 minutes at $37^{\circ} 30^{\prime} \mathrm{N}$ would translate to 144 minutes at $55 \mathrm{~N}$, assuming that the lowest order potential vorticity $f \partial \rho / \partial z$ is conserved. Regional historical data sets show a flow of high strength Labrador Sea Water south past the Flemish Cap, then southwest past the Tail of the Grand Banks and then west to the south of Nova Scotia. Apparently the southern cells are cast offs from this flow (although the possibility of a continuous meandering flow cannot be ruled out).

Figure 7 shows the deviations of CTD station 72 and the four adjacent stations, 987, 977, 976, 71, from the standard potential temperature salt curve. Potential temperature referred to 1500 decibars has been used since the anomalies are centered near this pressure surface. Stations 976 , to the south, and 987, to the north, show a transitional structure. The width of this cell is thereby estimated (from the station spacings) to be between 22 and 100 kilometers.

Figure 8 indicates that the second Labrador Sea anomaly is centered at station 980 with CTD station 73 showing slight negative anomalies and station 74, only 3 kilometers away and four hours later, showing a slight positive anomaly. The cell is estimated to be 30 to 65 kilometers in width. The third cell, included in Figure 9, has significant anomalies at CTD stations 77 and 78 and hydrographic station 986, indicating a cell width of 40 to 77 kilometers.

The negative anomaly cells found in the Slope Water in the $5^{\circ} \mathrm{C}$ to $10^{\circ} \mathrm{C}$ temperature range (Fig. 3b) are cells of Subarctic Intermediate Water. Figure $1 \mathrm{~b}$ shows that at $6^{\circ} \mathrm{C}$ the lowest salinities are found east of the Labrador Sea, where seasonal outcropping occurs. The terminology "Subarctic Intermediate Water" originates with Wüst (1928, 1935), and, according to Iselin (1936) and Worthington (1976), the water mass core is typically $6^{\circ} \mathrm{C}$ with salinities of less than $34.9 \%$.

Figure 9 shows the temperature structure for the station sequence 75-982-76983-984-77-78. Comparison between these stations shows that although positive and negative anomalies can be contoured on a section (Fig. 4) as continuous features, they sometimes cross density surfaces quite sharply. Normally, as shown in Figure $1 \mathrm{~b}$, such strong positive anomalies would be restricted to the south of $35 \mathrm{~N}$ at $55 \mathrm{~W}$ while the negative anomalies would normally be north of $41 \mathrm{~N}$. The third panel of Figure 9 emphasizes a large scale isopycnal mixing interpretation. Some event has brought a layer of Mediterranean type water to the north side of the Gulf Stream and a layer of Subarctic Intermediate Water to the southern part of the Slope Water giving a 250 kilometer wide region of anomalous water in the $5^{\circ}$ to $7^{\circ} \mathrm{C}$ temperature range. Isopycnal mixing would produce an end product close to standard Western North Atlantic Water.

As illustrated by Figure 10 , above $10^{\circ} \mathrm{C}$ and peaking at a density of $3.35 \mathrm{gm} / \mathrm{l}$, somewhat saltier water is being transported by both the Gulf Stream (CTD station 73) and the Slope Water (CTD station 80 ). Above about $13^{\circ} \mathrm{C}$ in both cases, there is then an abrupt transition: CTD station 73 to the temperature salt relationship of the standard curve, CTD station 80 to pronounced negative anomalies indicative of 


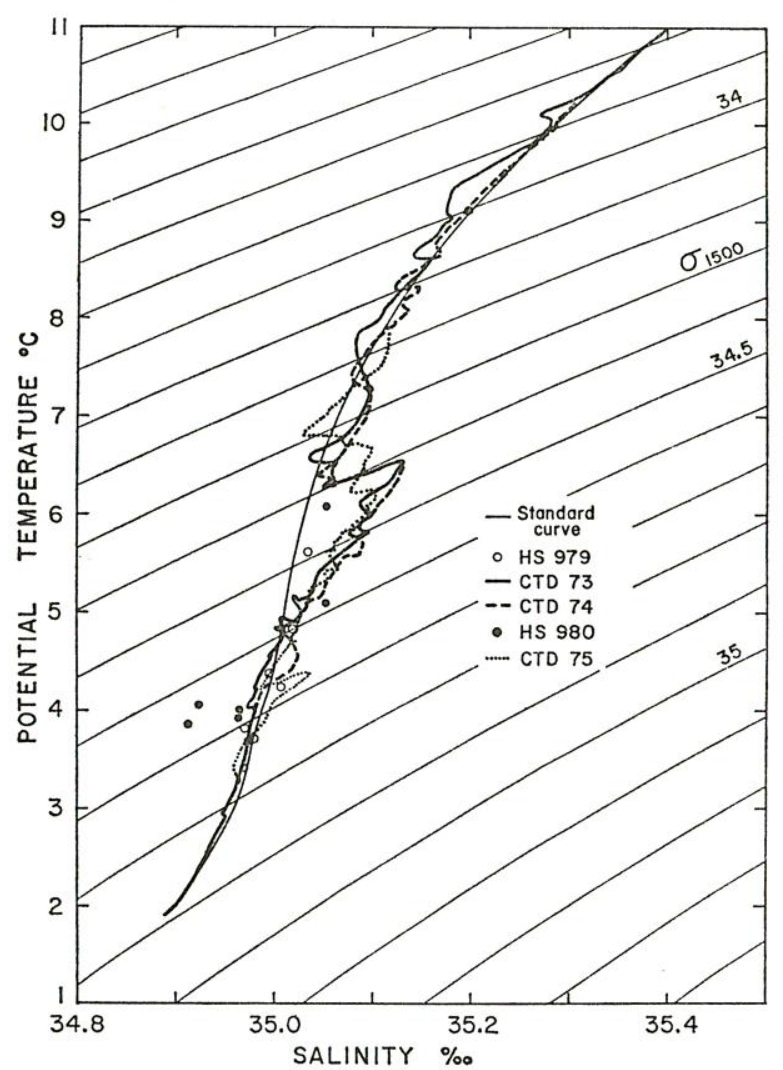

Figure 8. Potential temperature (referenced to 1500 decibars) salinity relationships for the stations associated with the second Labrador Sea Water anomaly. Other curves as Figure 7.

Slope Water. Figure $1 \mathrm{c}$ shows that we must look far east (to $40 \mathrm{~W}$ ) or south (to $25 \mathrm{~N}$ ) to find water of these salinities at $13^{\circ} \mathrm{C}$.

d. Eighteen Degree Water circulation. We found the Eighteen Degree Water during KNORR 60 to be quite low in salinity (Fig. 4). The associated dissolved oxygen content of about 4.8-4.9 ml/l is indicative of no convective renewal for several years, based on Jenkins (1977) estimated oxygen consumption rate of $.18 \mathrm{ml} / \mathrm{l} /$ year. The agent of convective renewal is heat loss to the atmosphere, hence the lack of convective renewal implies a smaller than average heat loss to the atmosphere. The explanation of the negative salinity anomaly of the Eighteen Degree Water is that the water had been warmed above the temperature normally associated with its salinity-namely about $0.5^{\circ} \mathrm{C}$ warmer.

During KNORR 66, the Eighteen Degree Water south of the Stream was much more homogeneous. At CTD station 72, the station with the deepest main thermocline, the temperature range from 171 meters to 474 meters is only $.08^{\circ} \mathrm{C}$, and the 


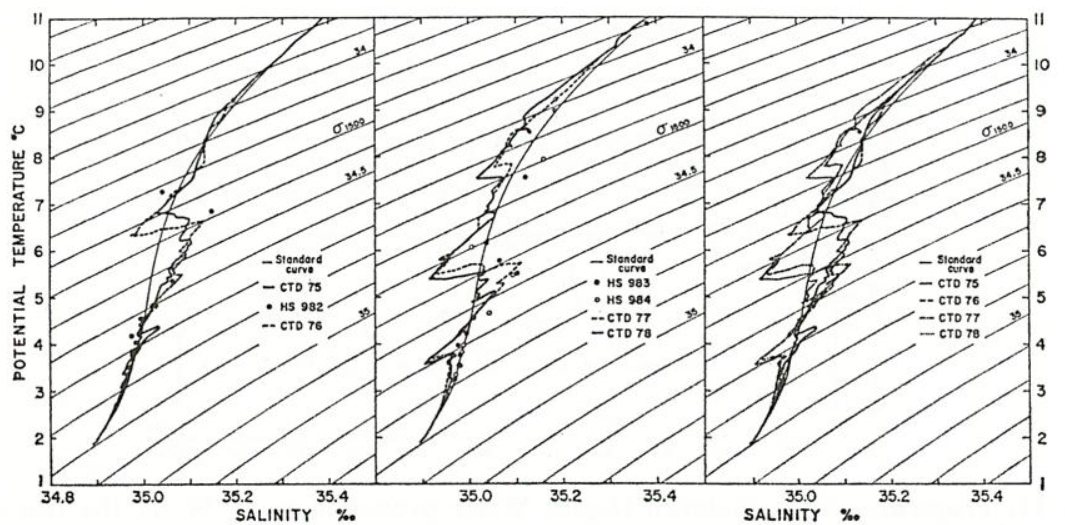

Figure 9. Potential temperature (referenced to 1500 decibars) salinity relationships for the stations associated with the cell of Mediterranean Water in the Slope Water zone. The first panel shows the stations from the southern half, the second panel shows the stations from the northern half, while the third panel shows the CTD stations alone. Other curves as Figure 7.

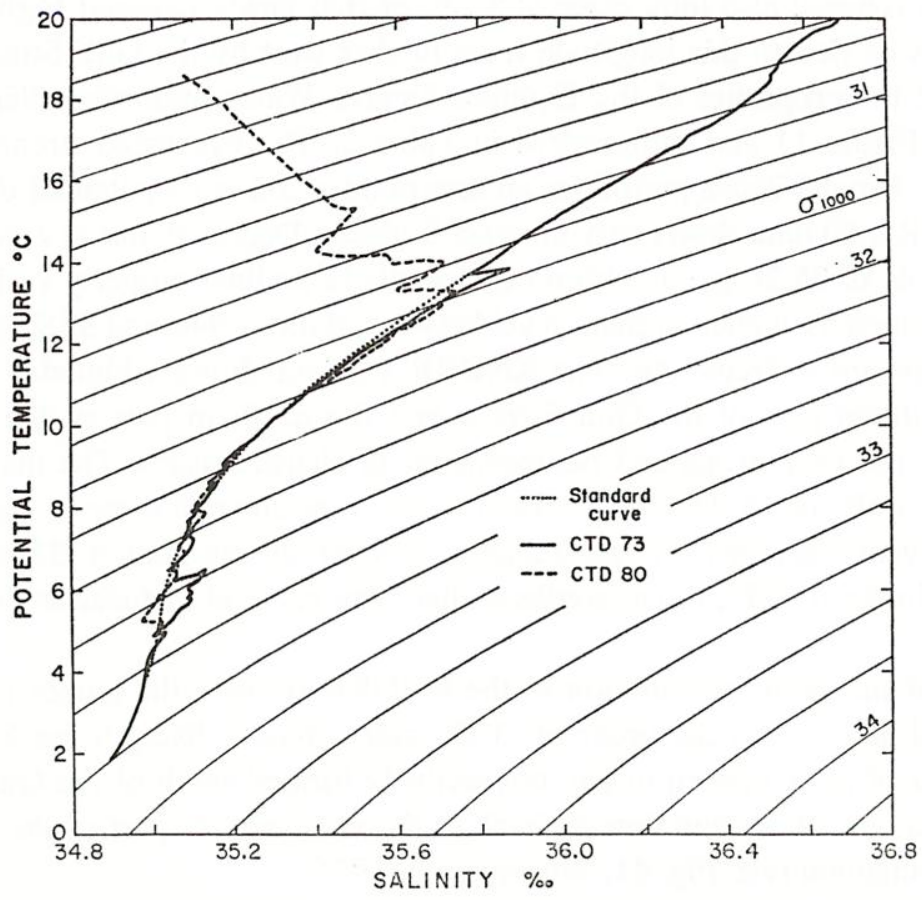

Figure 10. Potential temperature (referenced to 1000 decibars) salinity relationships for a station in the Gulf Stream (73) and a station in the Northern Slope Water (80). Anomalously saline water is found between $10^{\circ}$ and $13.5^{\circ} \mathrm{C}$. The western North Atlantic standard relationship is shown, and potential density anomaly curves are included, referenced to 1500 decibars. 


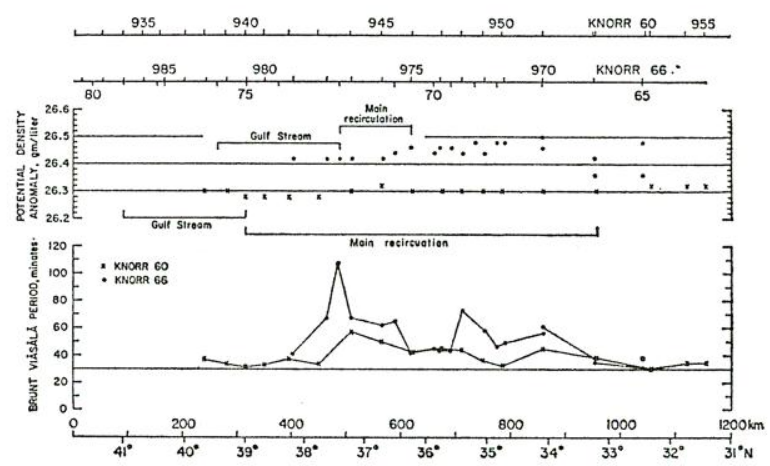

Figure 11. Properties of the Eighteen Degree Water pycnostad at $55^{\circ} \mathrm{W}$ for the two sections. The pycnostad strength indicator is the Brunt-Väisälä period (see text).

salinity anomalies are less than $.01 \%$. The oxygen values are about 98 to $99 \%$ of saturation value, compared to 85 to $90 \%$ of saturation for KNORR 60. It is known that the Eighteen Degree Water was convectively renewed south of the Stream at 70W during winter of 1976-1977 (Leetmaa, 1977). The KNORR 66 data suggest that either renewal also took place at 55W, or that newly renewed Eighteen Degree Water was carried to this longitude from further west by the Gulf Stream. A comparison of the properties of the Eighteen Degree Water pycnostad (Seitz, 1967) is shown in Figure 11 and summarized in Table 2. The pycnostad strength indicator used is the Brunt-Väisälä period for an interpolated $.02 \mathrm{gm} / l$ potential density layer. The KNORR 60 data shows very uniform Eighteen Degree Water at a potential density anomaly of $25.30 \mathrm{gm} / l$, with no systematic latitudinal property variations other than a moderately higher strength level between stations 944 and 948 , in the middle of the westward recirculation. The KNORR 66 data shows a bimodal distribution. In the southern part of the Gulf Stream and the northern part of the return flow the modes are very strong and homogeneous in characteristics. The mean temperature and salinity of $18.03^{\circ} \mathrm{C}$ and $36.490 \%$ are very close to those at the convective renewal event observed by Worthington (1977) at his station 33 at $34^{\circ} 30^{\prime} \mathrm{N}$, $71^{\circ} 18^{\prime} \mathrm{W}$ in April 1977, three months earlier. The mode at that station was $18.01^{\circ} \mathrm{C}$, $34.507 \%$.

South of the main recirculation in the KNORR 66 data the modes are distinctly colder and denser-on the order of $.3^{\circ} \mathrm{C}$ colder. This is likely to be Eighteen Degree Water of more eastern origin, convectively formed south of the Gulf Stream at perhaps $45^{\circ}$ or $50^{\circ} \mathrm{W}$, and flowing back to the southwest as part of the warm water general circulation (viz. Fig. 41, Worthington, 1976).

The Eighteen Degree Water distribution is suggestive then of the following scheme. In the strong winter of 1976-1977, the Eighteen Degree Water was convectively overturned. By the end of winter the region on the southern side of the Gulf Stream was filled with Eighteen Degree Water to a depth of 400-600 meters. 
Table 2. Eighteen Degree pycnostad properties, 55W, KNORR 60, October 1976, and KNORR 66, July 1977. (See Figure 11).

\begin{tabular}{|c|c|c|c|}
\hline Cruise & KNORR 60 & KNORR 66 & KNORR 66 \\
\hline hydrographic & $\begin{array}{c}938-951,954,955 \\
957,958\end{array}$ & $976-979$ & 970,975 \\
\hline Stations & - & 71,72 & $67-69$ \\
\hline Potential temperature & $18.48^{\circ} \mathrm{C}$ & $18.03^{\circ} \mathrm{C}$ & $17.74^{\circ} \mathrm{C}$ \\
\hline Salinity & $34.476 \%$ & $36.490 \%$ & $36.449 \%$ \\
\hline $\begin{array}{l}\text { Strength (Brunt- } \\
\text { Väisälä period) }\end{array}$ & $39.1 \mathrm{~min}$ & $65.4 \mathrm{~min}$ & $52.8 \mathrm{~min}$ \\
\hline Salinity anomaly & $-.055 \%$ & $-.003 \%$ & $-.016 \%$ \\
\hline
\end{tabular}

Temperature ranged from about $18.1^{\circ} \mathrm{C}$ in the west at $75 \mathrm{~W}$ to perhaps $17.7^{\circ} \mathrm{C}$ in the east at $50 \mathrm{~W}$. The warm water gyre is centered near $69 \mathrm{~W}, 36 \mathrm{~N}$, according to Worthington (1976, Fig. 41), so the post-winter circulation would carry the warmer modes east, then southeast, while the colder modes in the eastern extremity of the gyre would move southwest in the gyre recirculation. Thus three months later we find the northern part of the gyre at $55 \mathrm{~W}$ filled with $18.1^{\circ} \mathrm{C}$ mode water, while farther south is $17.7^{\circ} \mathrm{C}$ mode water. The average speeds for these two movements would be 20 to $25 \mathrm{~km}$ /day for the eastward advection, and about $10 \mathrm{~km} /$ day for the southwestward advection. POLYMODE mooring 1 , at $55^{\circ} 04^{\prime} \mathrm{W}, 35^{\circ} 53^{\prime} \mathrm{N}$, is centrally located in the westward recirculation. The mean velocity it recorded over 27 months, at 600 meters, was $7.7 \mathrm{~km}$ /day directed $13^{\circ}$ south of west. Geostrophic shear calculations suggest that at 350 meters, the mean velocity magnitude would be at least several kilometers per day higher, so the recirculation speed estimates for the Eighteen Degree Water are consistent with the current meter results.

\section{Discussion}

a. Summary of the KNORR 60-KNORR 66 contrast. Restricting the overall picture to a two-dimensional description, a gross meridional distortion of the normal water mass distribution has occurred during the nine month period. The upper water axis of the Gulf Stream shifted south, and the subtropical gyre westward recirculation concentrated at a more northern latitude. Anomalously high salinities at main thermocline temperatures between $11^{\circ} \mathrm{C}$ and $13^{\circ} \mathrm{C}$ normally associated with Mediterranean influence south of $32 \mathrm{~N}$ penetrated far northward under the surface expression of the Gulf Stream and are even found in the northern part of the Slope Water. At the base of the main thermocline too, high salinities are found much farther north than normal, with a thick, wide layer of pronounced high salinity anomaly being found beneath the Slope Water main thermocline in lateral contact with negative salinity anomaly Subarctic Intermediate Water. At colder levels, low salinity values associated with Labrador Sea Water are found abnormally far south.

What resulted was a very noisy temperature-salinity relationship in the $3.4^{\circ}$ to 
$13.5^{\circ} \mathrm{C}$ range, with very little water of the standard western North Atlantic relationship. The noise covers a variety of north-south scales. The largest continuous anomaly is at $5^{\circ}$ to $7^{\circ} \mathrm{C}$, and is continuous over 600 kilometers from the northern part of the gyre return flow across the Gulf Stream recirculation and the Gulf Stream itself, and well into the Slope Water. Cells of Labrador Sea Water of only tens of kilometers width and yet nearly pure characteristics are found over 800 kilometers from the nearest possible source, a westward flow around the Grand Banks of Newfoundland (Fig. 1a). Yet variations in anomaly strength of the same magnitude in salinity exist on scales of three and thirteen kilometers (viz. CTD stations 73 and 74 in Figure 8 and 77 and 78 in Figure 9). We do not have enough horizontal resolution to make an unequivocal statement as to whether the KNORR 66 section, when averaged, would show a significantly different temperature salinity relation than our standard. However, it appears that it does: at $5^{\circ}$ to $7^{\circ} \mathrm{C}$, the volumetric dominance of positive anomalies from the southern Slope Water to the south implies that salinities are on average more than $.02 \%$ higher than standard. Similarly, the two cells of Labrador Sea Water within and to the south of the Gulf Stream would seem to make the Gulf Stream and recirculation water fresher than standard by perhaps as much as $.02 \%$. Here we are on shaky ground already, since the cells we found are on the order of the mean station spacing in width.

b. Earlier observations of anomalous water masses in this sector. There is evidence that such meridional exchange events have taken place before. Worthington (1976) briefly described an earlier example: the 50W ATLANTIS section made in November 1956. The temperature and salinity sections can be found in Fuglister (1960). ATLANTIS station 5439 falls at the gyre center where the main thermocline is deepest, and thus is in the same relative position to the Gulf Stream in that section as CTD station 72 was to the KNORR 66 section. The ATLANTIS station shows a similar Labrador Sea Water cell of anomaly magnitude greater than $.02 \%$ stretching from 1300 meters to 2200 meters, with the strongest anomaly being $-.056 \%$ at about 1400 meters. Beneath the northern side of the Gulf Stream another negative anomaly cell is found at ATLANTIS stations 5434 and 5435. Worthington (1976) estimated that about one-third of the $18.7 \times 10^{6} \mathrm{~m}^{3} / \mathrm{sec}$ transported by the Gulf Stream between $3^{\circ}$ and $4^{\circ} \mathrm{C}$ was water of Labrador Sea origin in this section. Further cells of low salinity Labrador Sea Water and Subarctic Intermediate Water were found all the way north to the continental slope. At the northern end, a westward flow of $3.4^{\circ} \mathrm{C}, 34.92 \%$ water can be seen at the Grand Banks, at stations 5419,5420 , and 5421 , which would seem to be the ultimate source. The route to reach the gyre center from there is no doubt complex, requiring westward flow past the Grand Banks, eastward flow in the Slope Water Current, westward flow in the Slope Water Counter Current, and eastward flow in the Gulf Stream: where and how regularly such exchanges take place is not known. 
A further example of such exchange events in this sector is also contained in Worthington (1976). His Figure 23 repeated here as Figure 1b shows a cell of low salinity Subarctic Intermediate Water on three of the Gulf Stream '60 (Fuglister, 1963) sections, south of the Stream at a temperature of $6^{\circ} \mathrm{C}$. His Figure 25 shows that this was overlain by anomalously saline water at $10^{\circ} \mathrm{C}$.

The distribution of water masses in the North Atlantic (Fig. 1) would lead us to expect a broad scale gradation along $55 \mathrm{~W}$ from the lower salinity waters of subpolar and polar origin in the north to the higher salinity waters with Mediterranean influence in the south. While our sections show this broad picture to be correct, the gradation is found to be not at all smooth. Of the four data sets we have mentioned-ATLANTIS, Gulf Stream '60, KNORR 60 and KNORR 66-only KNORR 60 shows a smooth gradation. The others show much more uneven distributions, with evidence of extensive meridional exchange processes at work. We have described KNORR 66 as showing anomalous water mass distributions. Instead, perhaps it is actually more typical of this longitude than KNORR 60 .

c. Gulf Stream/Return Flow transport. The surplus volume of Labrador Sea Water at station 72 gives an abnormal thickness $(>375 \mathrm{~m})$ to the associated density layer. Since the vertical density gradients are normal above and below this anomaly, it must alter the calculated vertical distribution of dynamic height and potential energy for the station, and hence the shear velocity and transport calculations for the Gulf Stream, compared to what they would be if the density thickening were not there. The effect of removing the anomaly on the transport can be of either sign, or zero, since we can depress the main thermocline or uplift the deep water to compensate. We have not attempted this. The computed baroclinic transports for the KNORR 66 section are $41 \times 10^{6} \mathrm{~m}^{3} / \mathrm{sec}$ relative to 1000 decibars and $90 \times 10^{6} \mathrm{~m}^{3} / \mathrm{sec}$ relative to the bottom. KNORR 60 gave virtually identical values of 41 and $89 \times$ $10^{6} \mathrm{~m}^{3} / \mathrm{sec}$, respectively. Given the radically different water mass characteristics in the two sections, this constancy of transport is surprising.

We have seen that the baroclinic Gulf Stream transport, relative to the bottom, was about $90 \times 10^{6} \mathrm{~m}^{3} / \mathrm{sec}$ on both sections and that the westward return flow was about $60 \times 10^{6} \mathrm{~m}^{3} / \mathrm{sec}$. This leaves a local deficit of $30 \times 10^{6} \mathrm{~m}^{3} / \mathrm{sec}$. However, all modern circulation schemes for the North Atlantic must assume a flow of $30 \times$ $10^{6} \mathrm{~m}^{3} / \mathrm{sec}$ through the Caribbean Sea and the Florida Straits to accord with the measurements of Schmitz and Richardson (1968). If it is assumed on this basis that $30 \times 10^{6} \mathrm{~m}^{3} / \mathrm{sec}$ flow westward, south of our two sections, then the Gulf Stream gyre is in approximate baroclinic transport balance using the bottom as a reference level. Worthington (1976) had to assume that there was an additional westward flow of $39 \times 10^{6} \mathrm{~m}^{3} / \mathrm{sec}$ south of the Gulf Stream, so that he could bring the transport into balance. There is no need to assume such additional flows for the two KNORR sections. 
d. Origin of Mediterranean Water in the Gulf Stream and Slope Water. Where did the positive salinity water in the Gulf Stream and Slope Water come from? We can only guess. McDowell and Rossby (1978) reported a cell of Mediterranean Water in the southwest Sargasso Sea, about 200 kilometers in diameter and 600 meters thick. The water had significant positive salinity anomalies between $6^{\circ}$ and $14^{\circ} \mathrm{C}$. It was observed at $24^{\circ} 15^{\prime} \mathrm{N}, 69^{\circ} 02^{\prime} \mathrm{W}$ during October 1976 -the period when the KNORR 60 observations were being made. Reference to Figures $1 \mathrm{~b}$ and $1 \mathrm{c}$ shows that the McDowell and Rossby (1978) water was geographically not much farther west than water of these salinities is normally found. McDowell (1979, personal communication) reports that their "Meddy" was observed near its original location some nine months later. Additionally, the RESEARCHER data set from April 1977 some $10^{\circ}$ further north along $71 \mathrm{~W}$ contains no positive salinity anomalies. Thus it does not appear that we can explain our observations of main thermocline positive salinity anomalies along $55 \mathrm{~W}$ by the Sargasso Sea anticyclone carrying southeastern originating positive salinity anomaly water around the western side of the gyre. We expect the explanation instead lies with subgyre scale processes near $55 \mathrm{~W}$. The current meter data reported by Schmitz (1979) indicate an intensification of the westward return flow south of the Gulf Stream during the nine month period between the two hydrographic sections compared to the preceding eighteen months. The increased intensity would allow further propagation to the west of the positive salinity anomaly water normally found well east of $55 \mathrm{~W}$.

Wright and Worthington (1970) in their volumetric census showed that only a very small volume $\left(18 \times 10^{3} \mathrm{~km}^{3}\right)$ of Mediterranean water could be found in the Atlantic at temperatures greater than $12^{\circ} \mathrm{C}$. This water was confined to an area close to the Strait of Gibraltar. This finding confirmed Wüst's (1935) earlier study that characterized the most saline core layer of the Mediterranean Water in the Atlantic at $T=11.9^{\circ} \mathrm{C}, S=36.50 \%$ o. If the anomalously saline water (above $12^{\circ} \mathrm{C}$ ) found by McDowell and Rossby (1978) and by us, in fact originated as Mediterranean Water, one could postulate some convulsion of the Mediterranean outflow in the Strait of Gibraltar whereby an abnormally large volume of warm Atlantic Water was entrained into the outflow. Another possible mechanism for the production of this anomalously saline water could be that an eddy of warm Sargasso Sea Water became entrained into the Northern Gyre and eventually found its way back to the Sargasso Sea at a reduced temperature as the result of atmospheric cooling. A parcel of water cooled in this fashion would necessarily develop a positive salinity anomaly, provided that salt gain by the evaporative cooling was not cancelled by a low salinity surface layer being mixed downwards by the convection. A mild corroboration of this latter interpretation is the slight negative silicate anomaly associated with this water in the KNORR 66 observations, as opposed to the slight positive anomaly one would expect from Mediterranean Water. 
e. Speculations on the formation and maintenance of the deep waters of the North Atlantic. North Atlantic Deep Water represents about $71 \%$ of the water colder than $4{ }^{\circ} \mathrm{C}$ in the North Atlantic. Wright and Worthington (1970) based this percentage on a definition as follows. The North Atlantic was divided into six basins. A few potential temperature-salinity incremental classes in the cold water regime $\left(0-4^{\circ} \mathrm{C}\right.$ potential temperature, $\left.34.70-35.16 \%\right)$ are found in all six basins. The conglomerate of these classes is their definition of North Atlantic Deep Water. It is generally thought to represent a quasi-steady state advective-diffusive balance between five distinct sources: the two Norwegian Sea overflows (Denmark Strait and Iceland-Scotland Passage), the northward flowing Antarctic Bottom Water, the Mediterranean Sea Water, and the formation of Labrador Sea Water (Worthington, 1976). The western North Atlantic Water which dominates the volume of water warmer than $4^{\circ} \mathrm{C}$ and up to $19^{\circ} \mathrm{C}$ can similarly be regarded as an advective-diffusive balance between the large volume mode Eighteen Degree Water, South Atlantic Water, Subarctic Intermediate Water, and Mediterranean Water. There are a myriad of schemes of vertical mixing, isopycnal mixing, vertical advection, and horizontal advection that can be conceived of to maintain this balance. It is not our purpose to critically examine them in this paper. Rather, we will raise a point concerning the length and time scales involved.

Descriptive models in the past have implicitly assumed a quasi-stationarity, e.g., that one can look at a seasonal cycle on the western Sargasso Sea and thereby understand Eighteen Degree Water formation, or that a year of Gulf Stream ring statistics will be representative of the exchange of water between the Sargasso Sea and the Slope Water. There have been previous indications that such a view may not be true. We attempted a pre-winter to post-winter volumetric census comparison of the Eighteen Degree Water in 1974-1975, with KNORR cruises 43 and 48. That winter was mild, and convection did not reach to $18^{\circ} \mathrm{C}$. It appears that it did not in any of the winters between 1973 and 1976, and it was only with the winter of 1976-1977 that the RESEARCHER data (Worthington, 1977) yielded our first observation of an Eighteen Degree Water convective renewal event. With the 19741975 KNORR data we reported instead (McCartney, Worthington, and Schmitz, 1978) on a new, larger class of Gulf Stream rings, itself a departure from the traditional picture.

The shear large volume of North Atlantic Deep Water and western North Atlantic Water compared to the identified source water volumes is what leads one to this quasi-steady concept: small sources being steadily renewed and steadily mixing to maintain the large volume water masses with no measurable change in characteristics. The KNORR 60 and 66 data suggest an alternate event oriented formation process: once in a while a large horizontal scale layering event takes place in the Gulf Stream-Sargasso Sea system, which, in a short time (months), sets 
Table 3. Current meter mean velocities, POLYMODE Array 2, Mooring $837^{\circ} 30^{\prime} \mathrm{N}, 55^{\circ} 00^{\prime} \mathrm{W}$, 11 V 75 to 3 VII 77.

$\begin{array}{ccc} & 18 \text { month average } & 9 \text { month average } \\ \text { Nominal velocity level } & \text { V } 1975 \text { to X } 1976 & \text { X } 1976 \text { to VII } 1977 \\ 600 \text { meters } & 11.5 \mathrm{~cm} / \mathrm{sec} @ 15.9^{\circ *} & 3.6 \mathrm{~cm} / \mathrm{sec} @ 57.5^{\circ} \\ 1000 \text { meters } & 9.0 \mathrm{~cm} / \mathrm{sec} @ 17.3^{\circ} & - \\ 1250 \text { meters } & -2.9 \mathrm{~cm} / \mathrm{sec} @ 19.0^{\circ} & -\mathrm{sec} @ 10.5^{\circ} \\ 1500 \text { meters } & 8.3 \mathrm{~cm} / \mathrm{sec} @ 3.6^{\circ} & 4.2 \mathrm{~cm} / \mathrm{sec} @-24.9^{\circ}\end{array}$

* Angles measured counterclockwise from east.

up a juxtaposition of water types of much larger contrasts than normally seen. Given these larger gradients, the normal oceanic spectrum of eddies will give much larger exchange fluxes, and the anomalies may disappear fairly rapidly leaving a new standard ocean. This standard could be significantly different in its volumetric temperature-salinity characteristics than before the event. But as already pointed out, our KNORR 66 data show anomaly distributions that largely tend to cancel out, with the possible exception of the lower main thermocline and upper deep water.

The triggering mechanism for such a hypothesized catastrophic formation event could be a change in the mean current distribution of the gyre. For example, if the amount of rotation of the horizontal velocity vector with depth through the main thermocline and deep water was to significantly increase in one year compared to another, then the large-scale layering of water types seen in Figure 4 would result. POLYMODE mooring 8 has 27 months of data, and is positioned at $37^{\circ} 30^{\prime} \mathrm{N}$ in a region, of eastward mean flow. Table 3 shows the mean velocity vector magnitude and direction, for two time periods; the average for the first two settings (18 months) that precede KNORR 60, and the average for the last settings ( 9 months) between KNORR 60 and KNORR 66. The two sets of data are quite different. The mean velocity magnitudes are greatly reduced, and the veering with depth is much greater in the latter period. During the first period, the difference in direction between 600 meters and 1500 meters was $3.1^{\circ}$, and between 1500 meters and 4000 meters it was $15.4^{\circ}$. During the last nine months, the angles were much greater, $47^{\circ}$ between 600 meters and 1250 meters, and $35.4^{\circ}$ between 1250 meters and 4000 meters. Thus an increased layering tendency at $37^{\circ} 30^{\prime} \mathrm{N}$ is indicated for the nine months between the KNORR 60 and KNORR 66 sections. But is this cause or effect?

To find the ultimate cause of the observed changes, it perhaps is necessary to look at the water mass sources themselves. In the year and a half preceding the KNORR 66 cruise two of the sources are known to have undergone one of their apparently infrequent formation events. The Eighteen Degree Water formation event of March-April, 1977 has been mentioned already. As Worthington (1977) discussed, part of this event was a marked increase in the baroclinic transport of the Gulf Stream, from $81 \times 10^{6} \mathrm{~m}^{3} / \mathrm{sec}$ (relative to the bottom) obtained in April, 
1975, on KNORR 48, to $145 \times 10^{6} \mathrm{~m}^{3} / \mathrm{sec}$ (relative to the bottom) in April 1977 from the RESEARCHER observation at $71 \mathrm{~W}$. Such an increase in transport can be accomplished in two ways. One is maintaining a fixed gyre geometry and just increasing the mean speed, in which case no anomalous water mass distribution would occur. The other would be to have the Florida Current and the southern half of the gyre recirculations feeding the Gulf Stream contribute the increase, in which case more Mediterranean Water could enter the Gulf Stream.

The second known change in source water was in March, 1976, when a substantial convective formation event of Labrador Sea Water was observed (Lazier, personal communication, 1977), the first in perhaps nine years. Although a large volume of water was homogenized, it was of unusual properties: instead of a potential temperature of about $3.5^{\circ} \mathrm{C}$ as one might expect for Labrador Sea Water, it was $2.8^{\circ} \mathrm{C}, 34.88 \%$ - a water type associated with negligible volume in the Wright and Worthington (1970) standard ocean. Thus one of the ultimate source waters may have significantly changed its basic characteristics. Perhaps the KNORR 66 observations represent an adjustment reflecting this new source water.

Acknowledgments. This work was supported by the Office of Naval Research under Contracts N00014-74-C-0262, NR 083-004, and N00014-76-C-0197, NR 083-400, and by the International Decade of Ocean Exploration Office of the National Science Foundation under Grant OCE75-03962. The authors wish to express their thanks to the hydrographic and CTD teams for their careful station work during KNORR cruises 60 and 66, to Lorraine Barbour for processing of the hydrographic data. Helpful comments by Dan Georgi, Bill Schmitz, and Lynne Talley were much appreciated. This is contribution number 4334 from the Woods Hole Oceanographic Institution, and number 123 from the mid-ocean dynamics experiment, POLYMODE.

\section{REFERENCES}

Fuglister, F. C. 1960. Atlantic Ocean Atlas of T and S Profiles and Data from the International Geophysical Year 1957-1958, WHOI, Woods Hole, MA, 209 pp.

1963. Gulf Stream '60. Progr. Oceanogr., 1, 265-373.

Helland-Hansen, G., and F. Nansen. 1926. The eastern North Atlantic. Geofysiske Publikasjoner, 4 (2), 76 pp.

Iselin, C. O'D. 1936. A study of the circulation of the western North Atlantic. Pap. Phys. Oceanogr., 4, Number 4, 101 pp.

Jenkins, W. J. 1977. Tritium-Helium dating in the Sargasso Sea: A measurement of oxygen utilization rates. Science, 196, 291-292.

Leetmaa, A. 1977. Effects of the winter of 1976-1977 on the northwestern Sargasso Sea. Science, 148 (4313), 188-189.

Masuzawa, J. 1969. Subtropical Mode Water. Deep-Sea Res., 16, 463-472.

McCartney, M. S. 1977. Subantarctic Mode Water, in A Voyage of Discovery, Supplement to Deep-Sea Res., M. Angel, editor. 103-119.

McCartney, M. S. and L. D. Talley. 1980. The upper water thermostad family of the subpolar North Atlantic. Submitted to J. Phys. Oceanogr.

McCartney, M. S., L. V. Worthington, and W. J. Schmitz. 1978. Large cyclonic rings from the northeast Sargasso Sea. J. Geophys. Res., 83, 901-914. 
McDowell, S. E. and H. T. Rossby. 1978. Mediterranean Water: an intense mesoscale eddy off the Bahamas. Science, 202, 1085-1087.

McLellan, H. J. 1957. On the distribution and origin of the Slope Water off the Scotian Shelf and its easterly flow south of the Grand Banks. J. Fish. Res. Bd. Canada, 14 (2) 213-239.

Metcalf, W. G. 1969. Dissolved silicate in the deep North Atlantic. Deep-Sea Res., 16 Suppl., 139-145.

Needell, G. J. 1979. The distribution of dissolved silicate in the deep western North Atlantic Ocean. Submitted to Deep-Sea Res.

Richardson, P. L. 1977. On the crossover between the Gulf Stream and the Western Boundary Undercurrent. Deep-Sea Res., 24, 139-159.

Schmitz, W. J. 1977. On the deep general circulation in the western North Atlantic. J. Mar. Res., 35, 21-28.

- 1978. Observations of the vertical distribution of low frequency kinetic energy in the western North Atlantic. J. Mar. Res., 36, 295-310.

- 1980. Weakly depth dependent segments of the North Atlantic circulation. J. Mar. Res., this issue.

Schmitz, W. J., Jr. and W. S. Richardson. 1968. On the transport of the Florida Current. DeepSea Res., 15, 679-693.

Schroeder, E. H. 1963. North Atlantic temperatures at a depth of 200 meters. Ser. Atlas Mar. Environ., Folio 2. American Geographical Society, New York.

Seitz, R. C. 1967. Themostad, the antonym of thermocline. J. Mar. Res., 25, 203.

Talley, L. D. and M. S. McCartney. 1980. The circulation of Labrador Sea Water. In preparation.

Uchupi, E. 1971. Bathymetric Atlas of the Atlantic, Caribbean, and Gulf of Mexico. Woods Hole Oceanogr. Inst. Tech. Rept. WHOI-71-71.

Worthington, L. V. 1959. The $18^{\circ}$ water in the Sargasso Sea. Deep-Sea Res., 5, 297-305.

1970. The Norwegian Sea as a Mediterranean basin. Deep-Sea Res., 17, 77-84.

1972. Anticyclogenesis in the ocean as a result of outbreaks of continental polar air, in Studies in Physical Oceanography-A Tribute to George Wüst on his 80th birthday, A. L. Gordon, ed., Gordon and Breach, New York, 1, 194 pp.

1976. On the North Atlantic Circulation. Johns Hopkins Oceanographic Studies, Vol. VI. The Johns Hopkins University Press, Baltimore and London, $110 \mathrm{pp}$.

- 1977. Intensification of the Gulf Stream after the winter of 1976-1977. Nature, 270, 5636, 415-417.

Worthington, L. V. and W. G. Metcalf. 1961. The relationship between potential temperature and salinity in the deep Atlantic Water. Rapp. Cons. Explor. Mer., 149, 122-128.

Worthington, L. V. and W. R. Wright. 1970. North Atlantic Ocean Atlas. Woods Hole Oceanographic Institution Atlas Series No. 3, 190 pp.

Wright, W. R. and L. V. Worthington. 1970. The water masses of the North Atlantic Ocean; a volumetric census of temperature and salinity. Ser. Atlas Mar. Envir., 19, 8 pp., 7 plates.

Wüst, G. 1928. Der Ursprung der Atlantischen Tiefenwasser. Zeit. schr. Ges. f. Erdkunde, 507534.

- 1935. Schichtung und Zirkulation des Atlantischen Ozeans. Die Stratosphare des Atlantischen Ozeans. Wiss. Ergebn. Dtsch. Atlant. Exped. 'Meteor', 6, 1, 109-288.

Received: 4 April, 1979; revised: 30 November, 1979.

Printed in U.S.A. for the Sears Foundation for Marine Research, Yale University, New Haven, Connecticut, 06520, U.S.A.

Van Dyck Printing Company, North Haven, Connecticut, 06473, U.S.A. 
FOR UNCLASSIFIED TECHNICAL REPORTS, REPRINTS, AND FINAL REPORTS

PUBLISHED BY OCEANOGRAPHIC CONTRACTORS

OF THE OCEAN SCIENCE AND TECHNOLOGY DIVISION

OF THE OFFICE OF NAVAL RESEARCH

(REVISED NOVEMBER 1978)

1 Deputy Under Secretary of Defense

(Research and Advanced Technology)

Military Assistant for Environmental Science

Room 3D129

Washington, D.C. 20301

Office of Naval Research

800 North Quincy Street

Arlington, VA 22217

3 ATTN: Code 483

1 ATTN: Code 460

2 ATTN: 102B

1 CDR J. C. Harlett, (USN)

ONR Representative

Woods Hole Oceanographic Inst.

Woods Hole, MA 02543

Commanding Officer

Naval Research Laboratory

Washington, D.C. 20375

6 ATTN: Library, Code 2627
12 Defense Documentation Center Cameron Station

Alexandria, VA 22314

ATTN: DCA

Commander

Naval Oceanographic Office NSTL Station

Bay St. Louis, MS 39522

1 ATTN: Code 8100

1 ATTN: Code 6000

1 ATTN: Code 3300

1 NODC/NOAA

Code D781

Wisconsin Avenue, N.W.

Washington, D.C. 20235 


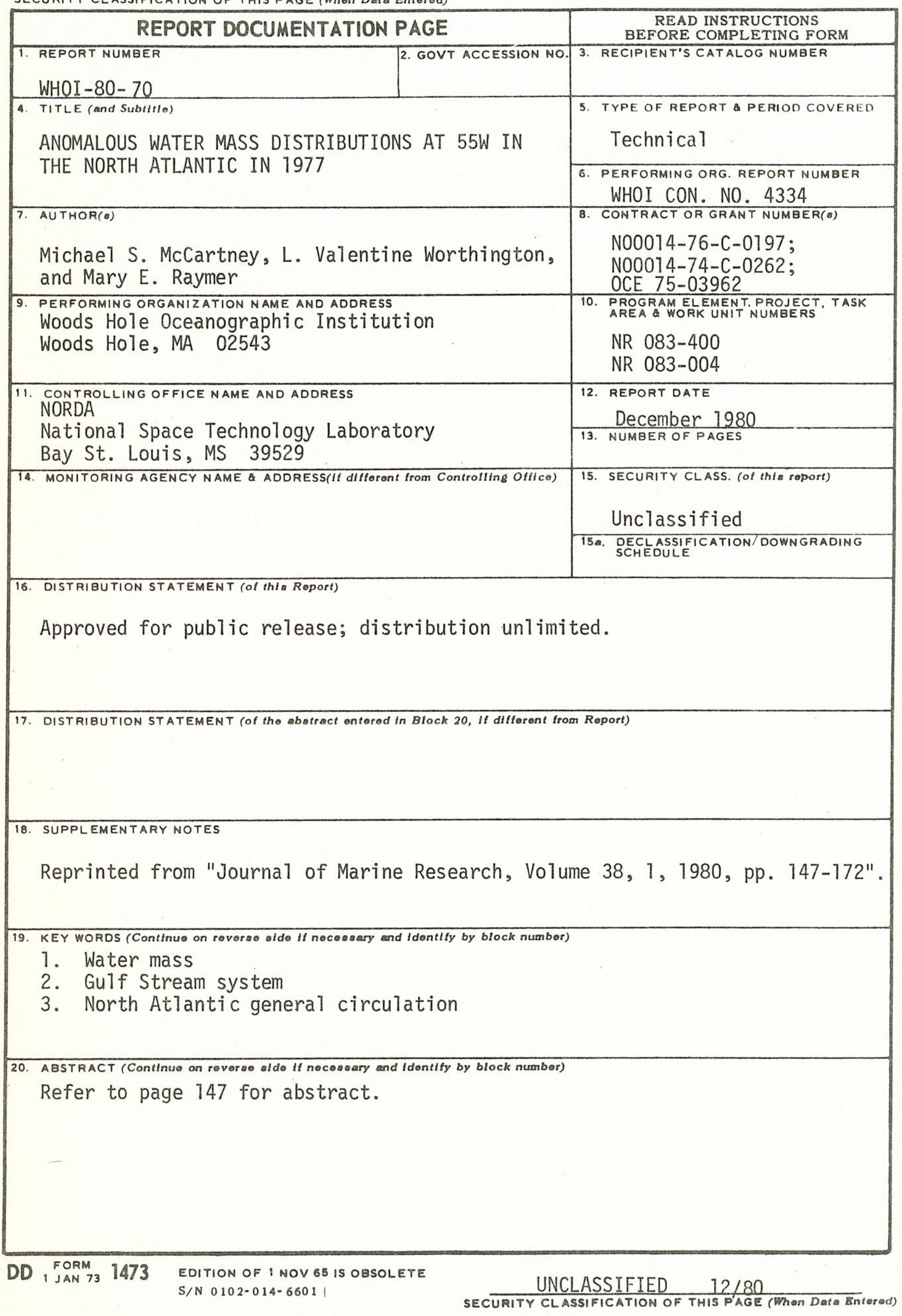




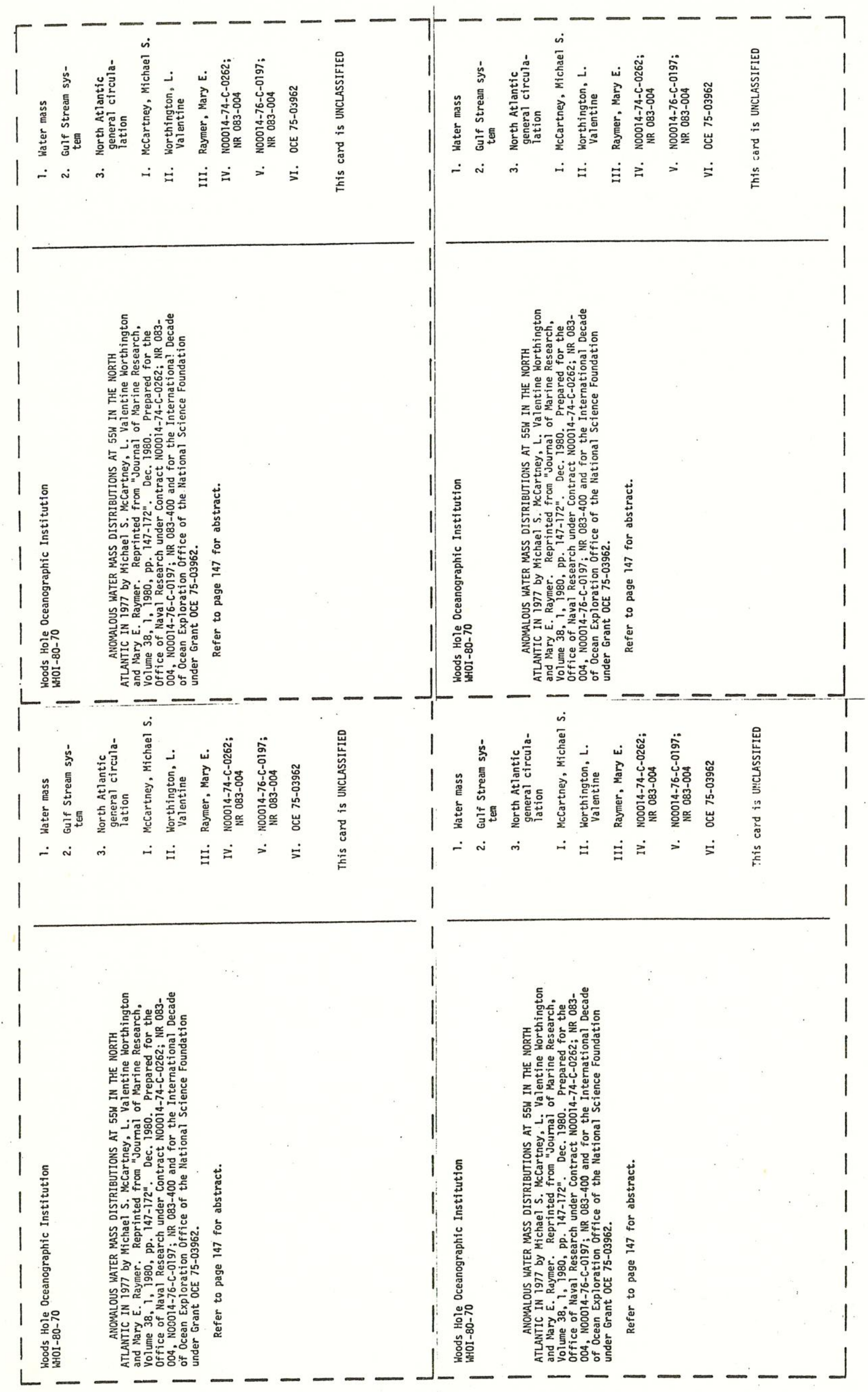

